BOTANICAL MEMOIRS. No. 12

\title{
INTRODUCTION TO THE SYSTEMATY OF
}

\section{INDIAN TREES}

By

A. H. CHURCH, M.A.

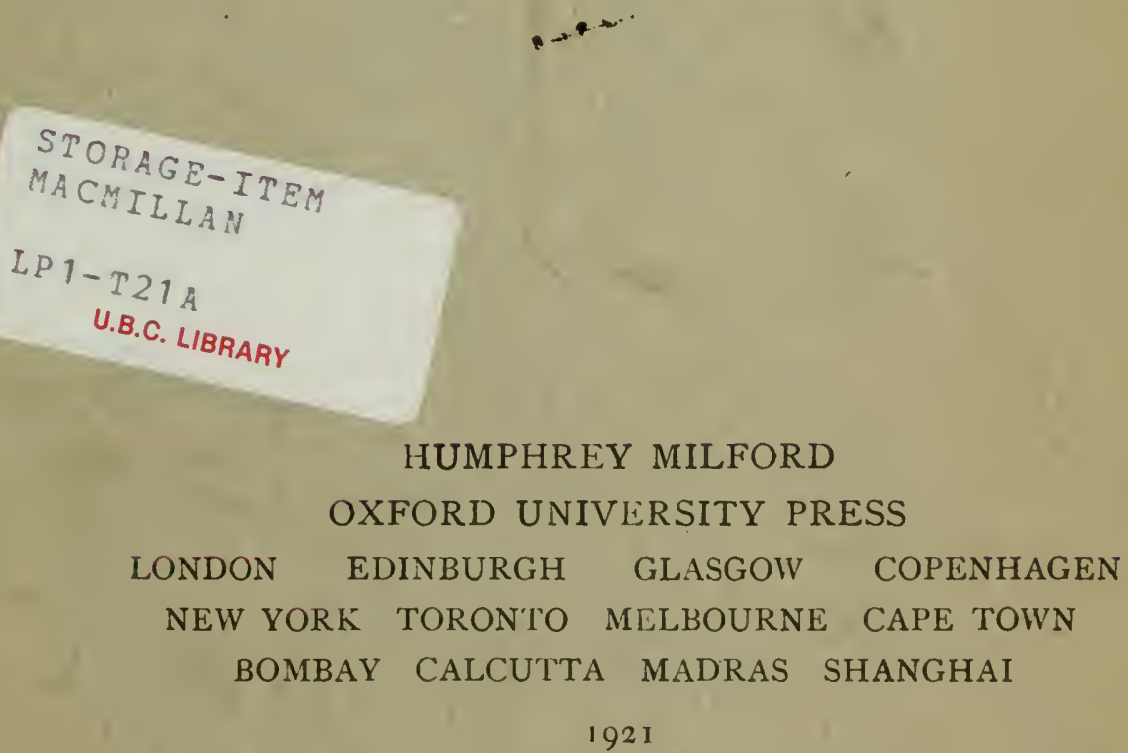

Price Two Shillings and Sixpence net 


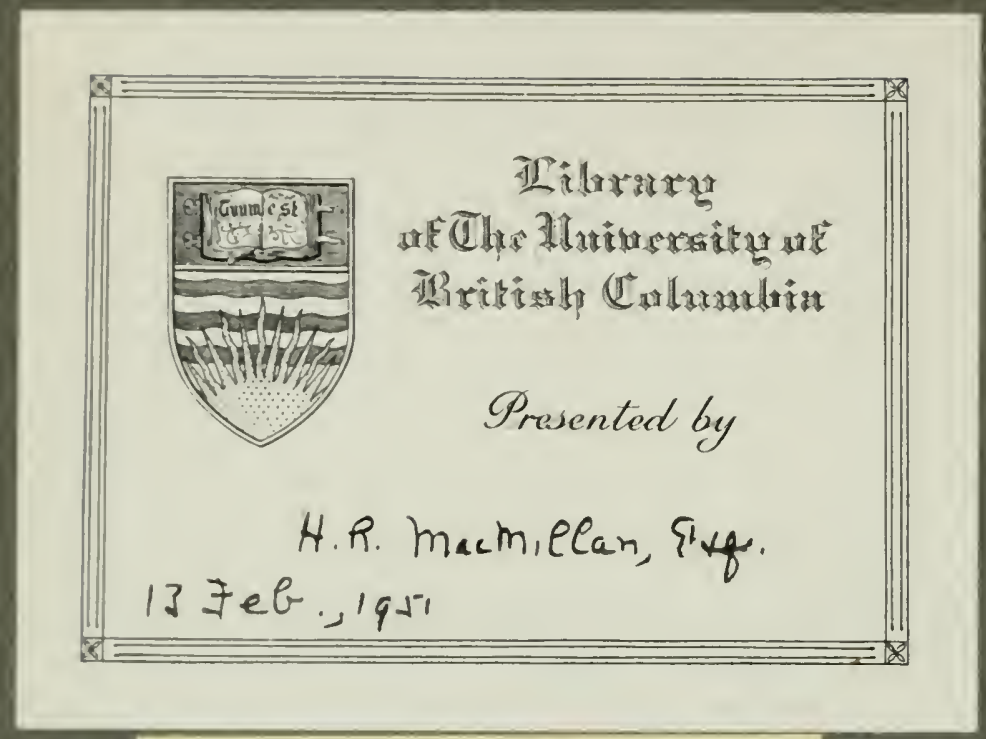

$$
\begin{aligned}
& \text { Mre MP. R.. Hare Villuse } \\
& \text { Bollertion in Forrastry }
\end{aligned}
$$

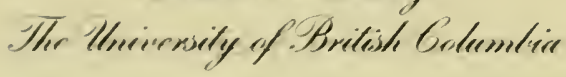




\title{
INTRODUCTION TO THE SYSTEMATY OF INDIAN TREES
}

By

A. H. CHURCH, M.A.

\author{
HUMPHREY MILFORD \\ OXFORD UNIVERSITY PRESS \\ LONDON EDINBURGH GLASGOW COPENHAGEN \\ NEW YORK TORONTO MELBOURNE CAPE TOWN \\ BOMBAY CALCUTTA MADRAS SHANGHAI




\section{CONTENTS}

I. INTROI)

II. Arocarpous Finilies . . .

III. CistiflORAE (Dilleniaceae, Bixaceae) . . . . . 9

IV. Cistiflorak (Guttiferae, Dipterocarpaceae) . . . . I 2

V. MALVALES . . . . . . . . . . 15

VI. DisciflorAE (Geraniales) . . . . . . . 18

VII. DiscIFLORAE (Sapindales) . . . . . . . 2 I

VIII. LEgumitosaE . . . . . . . . . 24

IX. Calicifiorie . . . . . . . . . 27

X. Bichrpellatie. . . . . . . . . 30

XI. Flciclic Gaiopetalae: INFer.le . . . . . 33

XII. APETALAE . . . . . . . . . . 36

XIII. MONOCILAMIDEAE (Urticales) . • . . . . 39

XIV. MoNochlamineat (Cupuliferae, \&c.) . . . . . 42

XV. PALMAE. . . . . . . . . . . +5

XVI. Gramineat: Gymosterms . . . . . 48

These notes have been arranged for the use of a class in Indian Botany; which has been held at the Botanic Department for Indian Forestry Probationers during recent years. 'The text sufficiently expresses the narrow limitations of the material and time available; it has been collected in the present form of 16 lecture-schedules, as affording a working draft for further amplification by students, in view of the bulky and expensive nature of more official publications: also as being something in hand, whicl, however imperfect, may serve as the beginning of a more definitely modern course of Tropical Botany.

BotiNic Gardin; OxHoRd, July, $192 \mathrm{I}$. 
INDIA comprises a botanical region of essentially Asiatic and tropical contimental area, ranging from primary evergreen rain-forest to the limit of Alpine plantlife at the higher elevations of the Himalya, including sub-equatorial swamps, mountain rain-forest and the deciduous monsoon-forest of dricr central tracts, the vegetation of grassy plains, estuarine mangrove-formation, sandy sea-coast, savannah and parklands, as well as tracts of dry arid sandy or stony desert, and affording examples of all types of tropical vegetation and cultivation.

such may serve as an introduction to the optimum ecological regions of the present world, on a scale and of a character wholly distinct from the impoverished vegetation of more northern latitudes, and the mediocre types of European or indigenous flora, which have long served as the elementary review of Systematic Botany. Under such optimum conditions plant-life may be still dominant, as well as enormously preponderant. Nuch of the area has produced forest continuously throughout known geological time; competition and natural selection continue to act on an intensive scale.

Botanical interest centres in forest-formation, as expressing the infinite possibilities of combination of the same generalized features of somatic organization in response to extreme biological factors as intensive insolation, problems of water and food-salt supply, peremnation over intense drought, the protection of the reproductive processes and of the developing seeds, the possibility of dispersal to unoccupied ground or of active competition in closed formations, and the critical stages of the successful germination of the embryo, as also of its juvenile condition.

The most characteristic feature is intense insolation, which gives practically unlimited supplies of pho:osynthetic carbohy'drate, in excess of the possible capacity for further proteid-synthesis, dependent in turn on the food-ions of the water-supply. IVaste polysaccharide is utilized in timber-production and xerophytic protective meclranism of sclerosed strands and layers, conspicuous also in massive capsules or sclerosed indehiscent fruits, as again in the production of starch or hydrocarbon fat and oil, giving enluanced possibilities of 'food-storage' for embryos in germination, or again as the sugars and organic acids of large succulent fruits utilized for the dispersal of seeds by animal agency.

Increased rates of metabolism follow higher temperature. Foliage-leaves may be reclioned in feet instead of inches, and the same applies to the development of the annual shoot. Flowers range to huge mechanisms, or may be reduced to the merest vestiges of economized systems. Pollination by bee-agency is less predominant in forest-formation; small mechanisms are associated with flies and insects with short proboscides; larger mechanisms grade to moth and bird-visitation.

Water-supply, regarded not only as the essential component of the dilute medium of living plasma, but also as the source of food-ions, is the primary factor in promoting ecological formations, and determining the evolution of types of ligher grade, according as the supply may be permanent, casual, seascnal, or practically non-existent. Methods of economizing the available supply become the rule, as few plants do not feel the strain at some time of the year, day, or of their individual life. Similarly all advancing stages of the ovary-chamber, which marks the evolution of the Angiosperm gynoecium, from the primary closing in of free megasporophylls to phases of syncarpy and the elaboration of the inferior ovary, are to be approached from this standpoint. The case of the 'green-fruit' affords conspicuous illustration. In evergreen rain-forest, flowers and fiuits of the upper exposed levels, competing with the foliage-leaves for water-supply, present advanced xeromorphic mechanism. In seasonal deciduous monsoon-forest green fruits subserve seed-protection into the driest months of the year, with increased devices of osmotic water-storage, sclerosed layers of massive ovary-wall, packing of the internal cavity with dry or succulent hairgrowths, succulent seed-arils, or lamellar extensions, the production of terpenes, 
glandular hairs. spinous emergences, wing-like slading laminae-all as mechanisms capable of subsequent utilization, more or less successfully, in the dispersal of fruits and seeds. Minor examples of such plienomena in trees of Northern latitudes illustrate the fact that all such adaptations were originally altained during the rigorous selection implicd in solving the problems of tropical regetation.

Forost Treos, taken as plants with perennial woody habit, ranging from small shrubs and climbers to massive timber-trees of hirh forest, are scheduled at 4,400 species (Brandis. 1911). those giving appreciable timber at 1,450 (Gamble, 1902), as conomically significant to the forester, 300 (Troup, r $9 \mathbf{I}_{3}$ ), and at least 200 may he regarded as generally important.

Systematy : For purposes of cataloguing and ready reference, plants are classifred in groups and sections (phyla), to families, genera, and species, the main outlines of which are still more or less empirical and largely traditional, though aiming at a 'Natural System'; i. e., one expressing genetic relationship. The recognition of even a 'species' is still arbitrary, and all classification may be regarded as provisional. The morphological organization of the flower, fruit, and seed, as including the complex processes of racial mechanism of reproduction, is generally utilized; since this covers the elaborate provision for the specialization of the floral shoot-system and its mechanism, as concerned with:-(I) the essential process of cross-pollination, or the approximation of the microspores to the vicinity of the megasporangium of the sporophyte-phase; (2) the elaboration of the ovary-chamber as the special feature of the Angiosperm; (3) the mechanism of seed and fruit-formation as allotted to postsexual nutrition and the care of the embryo; and (4) the structures associated with the dispersal, perennation, and germination of the seed. So complex and inter-related are the adaptations for these several functions, taken singly or in combination, that the somatic organization of the general vegetative and arboreal growth, its morphology and relation to insolation and desiccation, as expressing the nore immediate relation of the indizidual to its present environment, become of relatively subsidiary importance. Such data may be still significant in lesser degree; since though they are cqually the ecological inheritance of past ages, they appear on the whole less conservative in obscure mechanism, through which may be traced older factors in the evolution of flowering and seed-plants of more remote epochs.

Systems of Classification, though now admittedly aiming at phyletic presentation, are not to be criticized too strictly in this direction. A 'Sy'stem' 'is the official presentation of the subject at any given time, with which the individual botanist has little to do. Cataloguing and bookleeping have to be maintained as a common standard of reference. The limitations of species, genera, and families are commonly accepted, though subject to minor sources of error; these become the units of systematy. Official systems only differ as they reflect more modern outlooks for regarding the grouping and terminology of the larger sections. The arrangement of the latter in any linear sequence for book-presentation is largely a matter of convenience and convention.

Natural Classification aims at the arrangement which may most clearly visualize the phylelic progression of different races; but the life of every higher plant involves the balanced compromise in the solution of quite a number of distinct problems, ench requiring a set of complex specialized mechanism, adapted from the remains of past mechanisms of older phases of existence. Hence every race, genus, and species may show independently combined lines of evolutionary progression, or even of deteriorition, in many different directions differently, or at unequal rates. No very primitive or archaic plant can be now in existence: all may be highly organized in different respects, or present different horizons of attainment in the same category. All systematy thus encls in being artificial to some extent, and convenience is more important than pedantic discussion; after all, systematy is made for the advance of scientific botany, not zice versa, and classification can no longer be regarded as an end in itself.

The Modern System, based on the Natural System of Jussieu ( 7 89), extended 
by De Candolle (1818-73), has been officially organized in the Genera Plantarum of Bentham and Hooker (Kew, 1862-83), and further emended and extended in the Pflanzenfamilien of Engler and Prantl (Berlin, 1889-I908). Pending a further revision of the whole field by an accepted and competent authority, the text of the last stands as the ultimate appeal.

For purposes of general investigation a method of Plant Description is required, expressed in concise and readily intelligible phraseology, a method of interpretation of floral construction in terms of a Floral Diagram, and again as scale-drawings in Sectional Elevation: in addition, data for time-factors, and cletails of the working inechanism in relation to insects and other external agencies, the structural details of the fruit, and the biology of seed-dispersal. Much of the older literature is expressed in obsolete terminology which reflects antiquated points of view. Hence new descriptions, in plain English, new figures, and especially accurate data for floral biology and general ccology are urgently required; and the ficld is limitless.

The Genera Plantarum of Kiew; though obsolete botanically, is still largely official for British Government Departments. For present purposes the compromise aclopted by Brandis (I9II) will be followed as far as possible; this being so far the official presentation for Indian foresters. Large, well-differentiated petaloid flowers are conveniently dealt with first; smaller reduced, or more clementary forms presenting greater difficulty, may be taken later. Hence Polypetalous Thalamiflorae are followed by Eucyclic Disciflorae, and these by Calyciflorae. The Gamopetalae ('Sympetalac ') in turn by Monochlamydeae which comprise a mixture of some possibly' more archaic types with many undoubtedly reduced and secondarily 'apetalous'. Monocotyledons, as of minor arboreal importance are left till last, though containing phyla of extremely divergent and advanced organization; and some reference is made io Gymnosperms.

Though often minimized in Modem Botany, a practical acquaintance with a wide range of Angiospermous plants, their nomenclature and classification, is still an integral part of the equipment of every working hotanist; as an intimate knowledge of the living plant in all its phases and mechanism is the only sure basis for all economic or technological exploitation of available natural resources of the plantkingdom, on which the human race is still wholly dependent. The broadel lines of geograplical ccology, as also methods of culture and the utilization of economic products, are referred to standard text-books on Indian forestry :-

For General Literature, cf, :-

Brandis ( $19 \mathrm{II}$ ), Indian Trees.

Gamble (r 902 ), A Manual of Indian Timbers.

Troup ( I 9 I 3 ), Indian Forest U'ilization.

Tronp (192I), The Silviculture of Indian Trees.

Schimper (I 903), Plant Geography, Eng. Trans.

Engler-Pranll (1889-97), Pflanzenfamilien.

For Illustrations, cf. the older floras:-

IIight (Madras, 1840-50), Illustrations of Indian Botany, 2 vols.

Wight (Madras, I 840-50). Icones Plantarum Indiae Orientalis, 6 rols.

Roxburgh (1 795), Plants of the Coast of Coromandel, 3 vols.

Beddome (Madras), The Flora Sylvatica for Southern India, 2 vols.

Wallich (1830), Plantae Asiaticae Rariores, 3 vols.

Brandis (1874), Illustrations of the Forest Flora of North-West and Central India. 
APOCARPOUS FAMILIES are usually approached from the standpoint of the Ranunculaceae $(27 / 1200)$ of the N. Temp., but these are typically herbaceous types and are wanting in tropical forest : Clematis (170) alone is woody, including liana-forms climbing by leaf-petioles : cf. C. montana of Himalya, climber flowering in spring on slant spur-shoots; flowers $2-3$ in. diam.; perianth-segments $4(5-6)$, white; stamens 100-130; carpels 40-50, each with I functional ovule and rudinents of others; fruit as a cluster of achenes, I-seeded, with long hairy style enlarged and as-isting in wind-dispersal. C. lanuginosa, China, with many vars. and hybrids (Hort.): Howers large, solitary, terminating spring shoots, 6-8 in. diam.; per. seg. 6-8, pale violet-blue; stamens 100-200, caryels $100-120$; fly pollinated, with large achenes and long style persistent.

Magnoliaceae (9 100), essentially a family of tropical and sub-tropical trees, founded iSIS. These afford the nearest approximation to the general conception of what primitise Angiospermous flowering trees may have been in the past; hence appropriately begin the system.

Gineral fealuris; leaves large and simple, with a sheathing stipule-construction enclosing the next younger members. Flowers solitary and terminating the foliage-shoot, usually large and conspicuous, hermaphrodite, spirally constructed and indefinite. Pirianth trimerous, of the type $3+3+3$; Floral receptacle elongated and presenting distinct zones; Androecium of many stamens, separated from the gynoecium of numerous free carpels; the latter each reduced to a small ovary with 2 or more ovules, and with prolonged stigmatic tip. Usually protogynous and pollinated on first expansion by flies. Fruit ranging from dry dehiscent follicular type (usually dehiscing by the outer edge) 10 achenes; seeds with a small embryo in endosperm storing fatty oil.

As available forms of. :-

Magnolia conspicua of Japan (Hort.), flowering on the bare branches March, April, $3-t$ in. dian., perianth-segments white; stamens 50-60, with massive filaments; foral receptacle $1030 \mathrm{~mm}$. long; carpels 60 , each 2 ovules; mechanism markedly protogynous, not setting fruit (Hort.).

M. grandiflora of $\mathrm{N}$. Amer., 60-So ft. (Hort, in vars.); leaves large, evergreen, coriaceous, stipule 3 in.: Flowers $6-8$ in. diam., strongly scented, fly-pollinated; often semi-double; stamens about 60 , carpels 50 ; seeds $1-2$, the compact dry set $\left(3^{-4}\right.$ in.) of pods $(30 \mathrm{~mm}$.) dehiscing by external margin as well as by inner suture.

Liriodendron Tulipifera, Tulip 'Iree of N. Amer, and W. China, Hort.; handsome tree, $160 \mathrm{ft}$. and S-10 diam., with deciduous characteristically 4 -lobed leaves, and broad nat adpressed stipule pair, $1 \frac{1}{2}$ in. ; Flowers (June) solitary, 3 in., per. seg. grecnish-yellow with red flush, stamens 40 , carpels 100 ; fruit as indehiscent samaroid achenes with wing-prolongation, $2 \frac{1}{2}$ in., $\mathbf{1}-2$ seeded.

Indian forms include species of Magnolia chiefly from Himalyan regions.

Magnolia Campbelli, a large deciduous tree of E. Himalya; fowers on bare wood in manner of $M$. consficua, 6-10 in. diam., white or rose-coloured, fragrant; perianth segs. $12-15$; fruiting gynoecium elongated to $6-S$ in., woody carpels, $12 \mathrm{~mm}$. dehiscing along outer edge, seeds usually r, red, ro mm.

Michelia excelsa, a tall deciduous tree of E. Himalya (Darjecling); flowers white, $4 \mathrm{in}$. diam.; per. seg. 12, trimerous or tetramerous; stamens 100-120, carpels $50-60$, on a receptacle $13 \mathrm{~mm}$. long, spaced $5 \mathrm{~mm}$. from androecium; orules $3^{-4}$, stigma hooked; Fruiting portion elongated $4^{-S}$ in., lax, with follicular carpels, $\frac{1}{2}$ in., dehiscing on outer edge; seeds $10 \mathrm{~mm}$., with red sarcotesta, taken by birds.

Cf. M. Champocia, a large evergreen tree of E. Sub-Himalya and W. Ghats, much cult. ; Flowers $2-3$ in. diam., fragrant; per. segs. 15 , yellow-orange ; fruiting receptacle erect, extending to $3^{-6}$ in.; (lry follicles oroid, $20 \mathrm{~mm}$., dehiscing by outer margin, secds $3-5,10 \mathrm{~mm}$., with pink sarcotesta. 
Also note Tilauma Hordysoni in Hill-forest, Nepal, more greneralized in gynoecium, in fruit this becomes an erect and massive conoid aggregate, $4^{-6} \mathrm{in}$., with woody' carpels (roo or more), dehiscing normally by 'ventral' suture, and coming away from the axis.

Anonaceae (46/800), based on Amcrican forms of Anoma (1808), and extended to a wide range of trees essentially of tropical forest, witl simple leaves, cxstipulate. Flowers usually hermaphrodite and trimerous in perianth, of the type 3 'sepals', $3+3$ 'petals', giving floral mechani ms of high specialization, fly'-pollinated 'cliambertypes, often large and highly-coloured. The floral receptacle is usually condensed; the androccium of indefinite stamens with irregular arrangement as a platform of anther-facets; gynoecium indefinite of free carpels, the ovary-region reduced, and a specialized stigmatic surface. In fruit the carpels enlarge, with great range, often long-stalked, I-seeded or many-seeded, succulent or woody. The seeds are large, with small embryo in a conspicuously ruminated endosperm.

Wholly distinct from Magnoliaceae in fruit and seed-organization, convergent in elementary floral construction with trimerous perianth and small stamens and carpels closely compacted to a platform-mechanism, pollinated in a half-closed bud conclition. Indian genera $1_{5}$, including Saccopetalum and Miliusa of deciduous forest, Polyalthiu, Unona, Lraria, Anona. In the most characteristic foral mechanism the valvate 'petals' close in over the essential organs to constitute a damp protected chamber, access to which is permitted by slits or windows left between the petals. The original dehiscent fruit is seen in Anaxagorea zeylanica, a mere shrub; in others it is indehiscent, and each carpel tends to be sclerosed to a sub-spherical nut-like body, often long-stalked; a 'head' of fruits being in such case produced from one flowel' (Polyalthia). In Anona the entire aggregate of carpels may become coalescent and succulent, giving an edible many-seeded massive fruit; cf. A. squamosa, Sweet-Sop, cult. in tropics; flowers small greenish, 2 in., perianth of type $3+3+3$; aggregate of stamens hemispherical; the fruiting gynoecium enlarges to $2-4 \mathrm{in}$. diam., with seeds in soft succulent pulp: also $A$. muricata, Sour Sop, with pointed carpel-facets, $A$. reticulata, Custard Apple, also cult., fruit with pentagonal facets.

Canangium odoratum, evergreen tree, $30-60 \mathrm{ft}$., of $\mathrm{E}$. Indies, commonly cult. ; flowers in racemes of $2-6$, drooping on long stalks: calyx of 3 sepals reflexed, corolla $3+3$, petals to 3 in. long, yellow, very fragrant and convergent over floral apex to an approximate chamber, ultimately lax. Androecium of about 200 stamens, $2 \mathrm{~mm}$., closely compacted to a bution-like mass, $10 \mathrm{~mm}$. across; connective-apex as a spike. Gynoecium of 10-12 carpels; ovary-region with many ovules, and the stigmatic ends enlarged and fused to a central stigmatic head. Mechanism protogynous, fly-pollinated. Fruit a cluster of hard black 'berries' $20 \mathrm{~mm}$., with slight sarcocarp, each containing 6-10 seeds with ruminated endosperm.

Goniothalamus Griffithii, a small tree of the South and Burma, with typical flowers: sepals 3 ovate, $9 \mathrm{~mm}$. ; petals $3+3$, the outer whorl massive, 3 in., leathery ; the 3 inner alternating, $2 \mathrm{~mm}$. thick below, $20 \mathrm{~mm}$. long, cohering by valvate edges (with interlocking papillae) to a club-shaped chamber over the essential organs, leav: ing at the base 3 window-apertures $(5 \mathrm{~mm}$.) to the interior. Androecium of about 100 stamens, $3 \mathrm{~mm}$., closely packed. Gynoecium of about 20 carpels, free, closely packed on flat receptacle-apex; ovary $3 \mathrm{~mm}$., with ovules $4^{-5}$ seriate; style bent, $3 \mathrm{~mm}$,, with stigmatic flap. In fruit the carpels are $\mathbf{i}-2$ seeded, giving indehiscent berry-like structures on stalks, I in.

Saccopetalum tomentosum (Uvaria), a large tree in Sal forest and South: flowers $2-3$ in. long. Fruiting carpels dark-purple, $\mathbf{r}$ in. diam., on $\frac{1}{2}$ in. stalks, $3-4$ seeded.

Miliusa velutina, a tree of C. India and Sub-Himalya, 3 inner petals long, silky and veliety externally; dark-purple inside. Fruit a rounded cluster of stalked carpels, each $\frac{1}{2}$ in. diam. 
Polyalthia longifolia, a tree of S. India, planted in avenues; flowers yellowishgreen, in umbellate clusters; ripe carpels $\frac{3}{4}$ in. on $\frac{1}{2}$ in. stalks.

L'nona discolor, shrubby; flowers grecnish-yellow, $1-2$ in.; carpels clustered in fruit, on long stalks, I $\frac{1}{2} \mathrm{in}$., purple and clongated, $2-5$ seeled, and constricted between the seeds. Species of Unona and L'zaria tend to become climbers.

Of Orders in which the floral organization, though apocarpous, tends to be reduced to minimum constructions in terms of trimery and small size, note :-

Menispormaceae $(56 / 260)$, a family of characteristically stem-twining climbing shrubs, with panicles of numerous small flowers of the type, perianth $3+3$, the stamens reduced to $3+3$, and the carpels 3 or 1 , with usually one ovule per carpel. The fruits are drupaceous, to $\frac{1}{2}$ in. diam. The woody stcms commonly present anomalous organization of the lianoid-type with broad med. rays, and recurrent cambiums, cf. Cocculus, Cissampelos.

Berberidacoao $(8 / 50)$, based on the European Berberis, present trimerous flowers with ovary of $\mathrm{I}$ carpel, but with several basal ovules: the anthers dehisce by 2 'valves'. Fruit a berry' with I or more seeds. Several Indian sp. (r4) in Hillforest as slurubs. B. a'ulgaris in N $\mathrm{Il}$. Himalya, \&c.

A small series of aberrant forms, Lardizabalaccae, monoecious, anthers not valvate, carpels $1-3$, apocarpous, ovules over inner surface of wall, cf.:-

Akebia quinata, a pretty liana-form (Hort.), with 5 -lobed foliage-leares, and flowers (April) diclinous, trimerous, dull purple, in simple racemes. Carpellary flowers few, below and larger; per. seg. 3 , carpels $3+3$ (varying), distinctly apocarpous, with many ovules. Staminate flowers small and numesous; per. seg. 3 ; reflexed, stamens $3+3$, anthers dehiscing by slits.

For the Lauraceae, with limiting cases of dicliny, dimery, apetaly, and carpellary flower with $\mathrm{I}$ carpel and $\mathrm{I}$ ovule, but comparable valvate anthers, cf. 'Apetalous families', p. $3^{6}$. 
CISTIFLORAE in the wider sense conveniently include a vast range of types in which the fully petaloid flower attatns a normal pentamerous caly $\mathrm{x}$ and an apprarently whorled corolla; the androecium remains wholly indefinite, but the grnoecium becomes syncarpous, either by a gamocarpous zone to constitute a new unilocular ovary-chamber with farictal placintation, or by pocket-formations to a plurilocular condition with placentation a.vile, or ultimately basul. The carpels remain vestigial as mere stigmatic lobes, or may be wholly lost. Forms with unilocular orary and parietal placentation may be conveniently taken first (cf. Cohort Parietales, Gen. Plant., i 862).

In N. Temp. flora the series is commonly approached by the small group of Cistaceae $(4160)$ on which it was originally founded, based on the Mediterranean forms of Cistus; and again from the specialized families of the Rhoeadineae, more particularly as familiar in the special limiting cases of the Crucifer and Poppy:

The alternative line of progression with axile placentation, familiar in Hypericaceae, may be extended to the great tree-families of Guttiferae, Termstroemiaceae, Dipterocarpaceae.

The Nalvales alliance may be considered separately. Probably the oldest phase of the progression is to be traced in Dilleniaceae which remain predominantly apocarnous, and hence come at an early stage in older classifications (Gen. Plant., I 862).

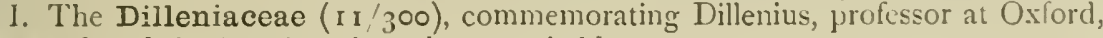
I $734-47$, founded 1818 , based on the remarkable type :-

Dillenia indica, a middle-sized tree of moist regions, cult., with large evergreen serrated foliage-leaves, and fine solitary white flowers, 6-1o in. diam.; sepals quincuncial,thick and fleshy; petals 5 , flimsy and fugitive ; stamens indef., all alike and inarching; carpels in a single cycle, $15-20$, fused along the massive conoidal receptacle, but free laterally; essentially apocarpous, with many ovules. The free white styles are linear and recurve over the golden-yellow androecium.

In fruit the gynoecium enlarges with the growth of the seeds $(8 \mathrm{~mm}$.) with little change; the massive sepals close over the carpels to give a succulent acid mass, $4^{-6}$ in. diam., and more than I in. thick over the enclosed carpels and seeds. Floating on water, eaten by elephants, but essentially for xerophytic protection of seeds on ground in hot season; seeds in protective mucilage; germination on the ground in sifu, assisted by ants.

D. pentagyna, a small tree of deciduous forest, $60-70 \mathrm{ft}$; foliage-leares $2-4 \mathrm{ft}$. Flowering in March, April, before the leaves: flowers yellow, I in. diam., in clusters from tuberous spurs on the older wood; reduced in number of parts; androecium of indef. outer stamens, erect and extrorse, with inner series of 10 recurved anthers on longer filaments. Gynoecium of 5 (6) carpels, free laterally, on a steeply conical receptacle, orules numerous; styles free, long and reflexed over androecium. Fruit with persistent sepals, I in., orange-yellow, taken by birds, similarly enclosing soft indehiscent carpels, each maturing I seed.

Cf. $D$. scabrella, very similar, flowers $1 \frac{1}{2} \mathrm{in.}$ diam. ; androecium of about 100 stamens, outer series 90, inner 10-1 2 reflexed over preceding; gynoecium of $5^{-6}$ carpels, frec laterally, but cutting in transverse section as if with axile placentation owing to elongation of receptacle. Flowers give pollen only and are nototribal to insects crawling over the lower extrorse anthers.

II. Bixaceae $(4 / 20)$ a small order separated from Cistaceae by the leares being spirally arranged instead of decussate, based on the inonotype-

Bixa Orellana, a shrub, indig. to Central America and cult. (Arnatto). Flowers I-2 in. diam., white or pink, of generalized Cistifloral habit. Petals flimsy; $\mathbf{I}$ in. ; stamens 200-300, with slender filaments as tassel-cluster, on a distinct collar-zone around the ovary. Gynoecium syncarpous, of 2 median carpels; the ovary, $3 \mathrm{~mm}$., covered with emergences; style stout, I 3 mm., ovules many; on 2 parietal placentas. 
Flowers offer pollen only; fruit a large dry bristly capsule $(40 \mathrm{~mm}$. by 30 ) opening by 2 valies along commissural lines. Seeds $20-25$ on each placenta, with red succulent ime:tment of papillose testa : endosperm stores starch.

Cochlospermum Gossypium, a small decicluous tree with soft spongy wood, of dry stony lull-tracts, the leaves large and palmately lobed, and flowers yellow, $4^{-5} \mathrm{in}$. diam. (suggestive of Cotton-plant). Stamens about 150 , and 5 deep, on slender filaments: ovary sub-globular, $6 \mathrm{~mm}$., unilocular wich is enlarged placentas, each with several rows of ovules (in the manner of a Poppy). Style slender, projecting beyond the stamen-cluster. In fruit the ovary enlarges to a fragile pear-shaped capsule, 3-4 in., and the seeds are clothed with long silky packing hairs, winddispersed. A remarkable xerophytic type, convergent with Gossypium of Malvales.

lieduced forms with dioecism have been referred to Flacourtiaceae $(70 / 500)$, $\mathrm{cf}_{0}:-$

Flacourtia Ramontchi, a small tree of dry hill districts, with thorny branches and small deciduous loliage-leaves. Staminate flowers small and apelalous; sepals $4^{-5}$. stamens indefinite, with a glandular extra-staminal disc-nectary and no ovary. (arpellary flower with ovary of 5-11 carpels, placentas meet in centre. Fruit an edible drupe, $\frac{1}{2} \mathrm{in}$., dark-red, pyrenae in two tiers, bird-dispersed.

Hydnucurfus Wightimu, a tall tree of moist forest of W. Ghats and S. India: flowers white, 1 in. diam., dioecious and irregular in construction; stamens 5 , stigmas and parietal placentas $3^{-6}$. In fruit the ovary enlarges to a spherical hard and woody shell, $2-4$ in. diam., indehiscent, with many large irregular seeds, $\frac{3}{4}$ in., with oily endosperm.

Tiralogenos Kurzii may be included in the same genus.

III. Capparidaceae $(34 / 450)$ includes some woody shrubs and climbers by stipular thorns. Flowers tetramerous in calyx and corolla, and more or less zygomorphic. Originally based on the Mediterranean-

Capparis spinosa, Caper, cult. ; corolla cruciform, large and showy, 2-3 in., white and pink later: fugacious, butterfly pollinated with tassel of stamens (60-1 20). The ovary is extended beyond the anthers on a long gynophore $(50 \mathrm{~mm}$.), and there is no style: gynoecium based on 6-S carpels, with prominent parietal placentas meeting in centre of cavity. Fruit $1-3$ in., seeds imbedded in pulpy septa. A highly specialized lype in floral construction and biology; as in the parallel Crucifer, the carpels are obsolete and the stigma-lobes commissural and secondary.

Cf. C. aphylla, a small iree (20 ft.) of dry regions; flowers red; $I$ in. over all; leaves small and shed in hot season. Fruit a red succulent berry, $\frac{1}{2}$ in. diam., on gynophore stalk, I in., taken by birds.

C. horrida, scrambling by thorns in hedges, and to a great height. Flowers pink or wlite, $\mathrm{I}-2$ in. diam., produced $c n$ masse. Fruil globose, $\mathrm{I}$ in. diam.

Crataeva religiosa, a small deciduous tree $(50-60 \mathrm{ft}$.) in damp situations and cult. ; flowers of typical Capparid habit, pink or yellow, in short terminal racemes, 2 in. diam, : the diagonal petals reflexed posteriorly in zygomorphic presentation; androecium of $12-20$ stamens, filaments $35 \mathrm{~mm}$; mechanism sternotribal: gynoecium based on 2 carpels, placentas meet in centre and bear many rows of ovules; gynophore bent forward, $35 \mathrm{~mm}$.: nectary-'disc' as cup-formation, $8 \mathrm{~mm}$. diam. Fruit a sub-globular 'berry', indehiscent, many-seeded, 1-2 in. diam., with hard rind.

IV. Moringaceae $(\mathrm{I} / 3$ ) a small order founded for:-

Moringa pterygosperma, a small deciduous tree of Sub-Himalya forest-zone, much cult.: leaves large, bipinnate, with small leaflets; flowers in panicled sy'stems, of highly specialized type, in the manner of Capparids but pentamerous with a long style. Markedly zygomorphic, with nototribal mechanism, I in. diam., white dotted yellow, fragrant. Stamens $10-12 ; 3$ posterior together with 4 alternating staminodes, unite below to a shield-piece over ovary, Gynoecium a stalked pod from the base of the perigynous receptacle-cup, $4 \mathrm{~mm}$., uniloc., with 3 parietal placentas and many ovules. Style $4 \mathrm{~mm}$., and stigma with 6 minute lobes. Fruit a long pendulous pod, 
9-18 in., dehiscing by 3 valves loculicidally, with a single series of large seeds with 3 -angled wing-edges, very characteristic, and no endosperm.

V. Tamaricaceae $(5 / 100)$ founded on Tamarix of S. Europe, as xerophytic and halophytic small trees, with foliage reduced to small adpressed scale-leares. Flowers very small, white or pink, in panicled spicate racemes : cf. :-

Tamarix gallica of sandy sca-shore (Nedit.), Hort. ; flowers typical, pentamerous, $5 \mathrm{~mm}$. over all; petals pinkish; stamens $\overline{-1 .}$ with a 10-lobed 'disc'-nectary'; gynoecium of 3 carpels, with 3 free stigmatic lobes, unilocular cavity, and orules from 3 basal placentas: in fruit the ovary becomes a small capsule ( $5 \mathrm{~mm}$.), dehiscing by 3 valves along commissural lines, and the seeds utilize a 'coma' of silky packinghairs from the chalazal region for wind-dispersal: germinating rapidly' on damp ground, but with little vitality.

T. Troupii, the common sp. in India (Baluchistan) to $30 \mathrm{ft}$., gregarious on alluvial tracts, essentially similar. $T$. indica, halophytic (Sundribans).

T. articulata, a middle-sized tree $(60 \mathrm{ft}$. and $2 \mathrm{ft}$. diam.) of dry regions and inundated land, withstanding extreme range of temperature and drought. Endramuli shed: flowers loosely panicled on long slender spilies: stamens 5, carpels 3 , capsule $3 \mathrm{~mm}$. 
1 divergent series of the Cistifloral alliance segregating families in which the gynocium presents preclominant axile placcntation, while the residual carpels are retained as free styles, stigmatic lobes, or may be wholly suppressed. Several large orders of tropical trees, with special characters in other respects are provisionally includerl.

I. Guttiferne $\left(43^{\prime} 820\right)$, including IIypericaceac of N. Temp.: otherwise essentially: of tropical evergreen forest with characteristic gum-resins, and the regetative shoots with eppesile and entire foliage-leaves. The flowers are large and solitary, or small and panicled, ranging to extreme phases of the type of tetramery, dicliny, reduction of orules per loculus, to the limit of output of one seed per flower. The frus:s are commonly indehiscent, dry; or drupaceous; but in some cases dehiscing capsules are still retained, cf. :-

Hypericum calycinum (Hort.), giving a good idea of the full type of floral organization (as available indigenous species of the genus illustrate reduction in size and numbers of carpels and stamens). Large blossoms $f$ in. diam., terminate woody shoots with persistent, simple, gland-dotted foliage-leaves, more or less D.V. in halit by the twisting of internodes alternately:

Flowers actinomorphic, pentamerous, hypogynous; calyx of 5 sepals, obviously quincuncial: corolla of 5 flimsy yellow petals, convolute in prefloration; each with notch, firm outside edge in bud, and crumpled inner lobe: tassel-type of llower giving pollen only: Androecium of 500 stamens, in 5 distinct antipetalous wroups shed separately; filaments slender, $25 \mathrm{~mm}$., anthers small: orary conoidal, $10 \mathrm{~mm}$., of 5 carpels, with free styles, $15 \mathrm{~mm}$., diverging among the stamens, antisepalous: stigmas presented at sane distance from axis as the pollen: ovary 5 -locular; placentation axile below (parietal above apex of floral axis), with T-headed placentas meeting in centre, and many small orules. Capsule $20 \mathrm{~mm}$., dehiscing in upper portion by 5 valves (each taking a style); seeds $2 \mathrm{~mm}$., with small straight embryo, and endosperm storing fat.

Garcinia Mangostana, as a diclinous variant (genus of $\mathbf{r} 80 \mathrm{sp}$.$) : evergreen$ tree, $60 \mathrm{ft}$., with coriaceous leaves, in general trop. cult. (Mangosteen). Flowers solitary, axillary, or $\mathbf{1}-2$. Staminate flower rare. Carpellary plant cult. and selfsetting: usually tetramerous in (aly $\mathrm{x}$ and corolla, 2 in. diam., ovary 5-8 locular, sigmal peltately lobed: seeds in white pulp of dark-purple fruit witl thick resinous hard tind, 2-3 in. diam.

G. Morella, S. Ind. and Ceylon, cult, for gun-resin (Gamboge), cf. G. Hanburyi; of Siam: flowers small, greenish-white, $\frac{3}{4}$ in. diam., diclinous and tetramerous; staminate flower with a short 4 -sided 'column', bearing many short-stalked monothecic anthers : carpellary flower with staminodes and a 4 -loc. ovary : fruit $\frac{3}{4}$ in. diam., with + seeds.

Calophyllum Inophyllum, evergreen tree of S. Ind. coast-forest, cult.; leaves entire, elliptic, shining coriaceous, with closely parallel lateral veins: flowers diclinous, 1 in. diam., cream-white and fragrant, tetramerous: staminate flower with stamens in $4^{-6}$ clusters and aborted ovary: carpellary flower similar in diagram, 2 inner sepals larger. Staminal 'bundles' antipet.; ovary of 2 carpels, witl 2 -lobed stigma and cavity uniloc., with one basal anatropous ovule. Fruit a yellow drupe, $\frac{1}{2}$ in. diam., taken by bats, \&c.

C. elatum (Iomentosum) Poon Spar tree of S. Ind., to $150 \mathrm{ft}$., evergreen forest of IV. Ghats. Flowers m panicles, 2 inner sepals petaloid.

Poeciloneuron indicum, of S. Ind. evergreen forest, more or less gregarious. Flowers pentamerous, stamens $16-20$, anthers remarkably 6-10 septate in loculi transversely: ovary of 2 carpels, 2 ovules in each loculus. Fruit $\frac{3}{4} \mathrm{in}$. dehiscing by 2 valves, 1 -sceded.

Mesua ferroa, evergreen forest-tree of E. Bengal and $\Lambda$ ssam, much planted: 
Flowers large white and Cistus-like, with grolden-yellow tassel of anthers, but tetramerous; stamens to 1,000 on collirr-growth: ovary of 2 carpels, 2 -locular, 2 orules basal in each loculus. Fruit I in., woody, 2 valved, shedding $r-4$ seeds.

II. Ternstroemiaceae (Theaceae, $16 / 200$ ). A series of more generalized types, the Cistifloral flowers being associated with older spiral leaf-arrangement, the leaves simple, serrate, without stipules, and the plants without resin-glands (leaves not gland-dotted).

Camellia Thea, Tea, a shrub or small tree of Assam, planted Ceylon, \&c., leaves $\mathbf{I - 2}$ in., flowers white, $\frac{3}{4}$ in., singly in leaf-axils, pentamerous; stamens 50 or so; gynoecium of 3 carpels with 3 styles and 1 ovule in each of 3 loculi. Capsule 3 -angled, dehiscent loculicidally, seeds 3 , not winged. Cf. Ternstroemia juponicu, a large deciduous trec of Hill-forest; Eurya, dioecious with indehiscent fruit; Gordonia with winged seeds.

Schima Wallichii, semi-gregarious in Hill-forest, N. Bengal, 80-100 ft., leaves $4^{-6}$ in.: flowers of Thea-type, 2 in. diam. Capsule $\frac{1}{2}$ in., with $3 \frac{1}{2}$-in. flat winged seeds.

III. Dipterocarpaceae $\left(16 / 3^{2} 5\right)$, a family of fine timber-trees of Indo-Malay, with representative species, many more or less gregarious. Leaves spirally arranged, stipulate; inflorescence as multibranched panicles with cymose tcrminals (monochasia) : flowers pentamerous, calyx quincuncial with heterodromy; corolla convolute in prefloration; androecium of 5 -IO or many stamens; gynoecium of 3 carpels, ovary 3 -locular with axile placentation and 2 ovules in each loculus, but $\mathrm{I}$ seed only sets in the normally indehiscent fruit. Cotyledons massive, storing fat, and remaining in the seed at germination. The characteristic new feature is the manner in which 23 , or 5 sepals, are extended to laminae which are utilized for spinning the fruits.

Shorea robusta, Sal, gregarious, dominant and characteristic of Central India and $\mathrm{NE}$. in deciduous forest, on two sides of Gangetic plain; to I $20 \mathrm{ft}$; the Dipterocarp farthest north, flowering en masse when partially leafless, March.

Inforescence as terminal and axillary panicles, 6 in.; ultimate monochasia with flowers 'sessile', 15-18 mm. over all: sepals $3 \mathrm{~mm}$., with soft grey hairs; petals convolute, ro mm., dull orange-yellow with soft pubescence, fugitive: androecium of about 30 free stamens, 3 deep; filaments $3 \mathrm{~mm}$., with broad sheathing base and anthers with awl-like connective-process as a trigger-nechanism, pollen-dusting; no specialized nectary. Gynoecium of 3 carpels; ovary sub-globular, 2 mm., style simple, stigma 3 -lobed; 2 anatropous ovules in each loculus.

In Fruit the 5 sepals increase in size; 1,2 , and 3 , mucl more than the others, to 2-3 in. long, each with 10-15 parallel main veins, as photosynthetic and protective to green fruit, utilized later for dispersal mechanism, by strong winds (June): germination hypogeal and immediate.

Cf. Representatize Species, essentially similar in flower and fruit, S. Tumbuggaiu in Cuddapah; S. Talura in. IV. evergreen forests of Kanara; S. Assamica, Makai, in Assam; S. oltusa, Burma, \&c., also sp. in Borneo, Amboina, and Cochin China.

Hopea odorata, a fine tree of Burma, roo-r20 ft., Thingan; in moist tropical forest, non-gregarious, with shining dark-green drooping leares. Inflorescence of similar terminal and axillary panicles, ultimate monochasia of small greenish-yellow flowers, $10 \mathrm{~mm}$. diam., much as Shorea, but corolla gamopetalous below and shed with androecium in one piece; petals convolute with frilled ends; androecium of $I_{5}$ stamens (in 3 alternating whorls of 5 ); connective-process as long as anther ( $1 \mathrm{~mm}$.); gynoecium of 3 carpels, 2 ovules in each loc., one seed sets. Fruit a small nut, $8 \mathrm{~mm}$, with sepals $\mathbf{I}$, 2, only free and extended to broad wings, 2 in. long, and very characteristic.

Parashorea stellata, evergreen tree, $\mathbf{5}_{5}$ o ft., of Martaban and the Malay Peninsula. Flowers small cream-coloured; sepals and petals relvety; stamens i 5 ; all 5 sepals equally extended as 'wings' of fruit, $2-3$ in. long, the nut velvety' and exposed between their bases. 
Pentacme suavis, a large more deciduous tree, gregarious in Upper Burma, with showy panicles of yellow flowers, $\frac{3}{4} \mathrm{in}$. over-all, balloon-shaped; stamens $\mathbf{I}_{5}$, connective and 4 anther-tips equally prolonged as 5 awl-like processes. All the scplals cnlarge in fruit, but $\mathbf{~}, 2$, and 3 , are larger, 3 in.; the fruit, $20 \mathrm{mn}$., being exposed between their bases.

Dipterocarpus tuberculatus, In (Eng), large gregarious tree, dominant and characteristic of Isurmese Indaing-forest on laterite; coriaceous foliage-leaves to is in. long and $y_{4}$ broad, deciduous in hot season. Inflorescence of a few $(4-7)$ fowers in axillary clusters towards ends of branches, as reduced cymose systems. Flowers dull-purple, 2 in. across, with contrasting grey tomentose calyx: receptacle slightly crateriform. Caly $x$ a massive gamosepalous tube, $10 \mathrm{~mm}$., closely investing the essential organs, with slight commissural ridges. Free segments quincuncial, and I, 2, to $15^{-20} \mathrm{~mm}$., the others half as long. Corolla markedly convolute (L in R-hand flower). Androccium of $30(1 \bar{j}+10+\bar{j})$ stamens, symmetrically spaced; connective-extension $2 \mathrm{~mm}$. Gynoccium of 3 carpels; upper part of ovary massive, style straight, with 3 minute stigma-lobes. Trigger-mechanism and no obvious nectary.

In fruit the style is broken away leaving a stout pointed nut, $20 \mathrm{~mm}$., I-seeded, with large folded cots., and enclosed in massive woody calyx-tube, $1-1 \frac{1}{2}$ in. diam.; the wings of scps. 1 and 2 are $6-7$ in. long and $I$ in. broad, 3 -veined; sepals $3,4,5$, small and reflexed. The commissural ridges are enlarged and 'tubercled' above. The spinning-mechanism depresses the 'wings' on a ro-inch circle. Germination hypogeal and immediate. An advanced xeromorphic type. Other forms characteristic of moist, more evergreen tropical forest are:

D. turbinatus, Kanyin, a tall tree ( $5_{5} \mathrm{ft}$.) of mixed forest in Burma, very similar, but lacks the tubercled commissural ridges, the wings smaller, $5 \mathrm{in}$. In $D$. costatus and $D$. alatus the ridges are greatly exaggerated, and there is much variation in details of fruit. For representative species cf. D. zeylanicus of Ceylon, $D$. indicus of $\mathrm{W}$. Ghats, D. Bourdilloni of Travancore $150 \mathrm{ft}$. and $5 \mathrm{ft}$. diam., D. pilosus in damp evergreen forest Assam, with wings 7-9 in., D. Djeri, Cochin China.

Cf. also Vatica Roxburghiana, of evergreen forest of S. Kanara and Ceylon; fruit subglobose, $I-1 \frac{1}{2}$ in. diam., woody and hairy, retaining 3 coriaceous sepals, but not 'winged'.

Vateria indica, evergreen forests of $\mathrm{W}$. Ghats, and cult.; with gum-resin (Piny Varnish): In fruit $\left(2-2 \frac{1}{2}\right.$ in.) the sepals are reflexed and dehiscence is by 3 valves. Seeds large and storing fat (Piny Tallow); stamens 40-50; possibly the most generalized of the family. 
MALVALES include a large section with general Cistifloral claracters combined with minor points of higher-grade specialization, remarkably constant, which may be checked with comparative facility, hence affording convenient clues to classification: cl. 'ralvate' sepals, a 'column ' type of androccium, nectary'-glands on sepals, and often 'monothecic' anthers (two-locular). Three great alliances have been given family status :-

1. The Malvaceae as the key' group, with elaborated floral mechanism, including the full set of characters previously mentioned.

II. The 'liliaceae, a tree family, in which the fowers present simple reduction variants, which may approximate the more generalized Cistifloral stock.

III. The Sterculiaceae, in whicl the widest range obtains from high-grade pollination mechanisms to most reduced (fly-pollinated) limiting expressions.

In N. Temp. regions the series has been approached from the standpoint of Malz'a and Tilia of N. Europe. In the Tropics all 3 families attain considerable importance, not only in floral organization, but as giving fine timber-trees of forestformation, as well as econonic products, textiles, fruit.

I. Malvaceae (33/900), typically with pentamerous petaloid flowers, actinomorphic, with 'epicaly's' of bracteoles, convolute corolla, column-like androecium, connected with the corolla and shed in one piece, as the complex prolongation of a festooned androecial tract, with monothecic 'anthers' producing large spinous pollen-grains. Carpels in one cycle; few, large and multiovulate, or many with I ovule each. Fruit a capsule, dehiscent, or no longer so, or as indehiscent I-seeded 'cocci', separated from the floral receptacle.

Cf. Althaea rosea, Hollyhock, herbaceous perennial, for fine flowers, $3-4$ in. diam.; epicalyx 6-lobed, anthers $240-400$, monothecic, in antipetalous crests of double pairs, on a column $20 \mathrm{~mm}$. high; carpels $40-50$, each I ovule : fruit separating dry flat cocci, $8 \mathrm{~mm}$. Malia sylvestris, reduced indig. form, anthers to 80 , carpels to 15 .

Gossypium herbaceum, Cotton-plant of Old World. Cult, in annual rotation. Leaves palmate, flowers yellow with purple spot at base, continued in leafy lateral monochasia ; epicalyx of 3 laciniate segments; typical column-androecium with clustered anthers; carpels 3. ovary syncarpous with many ovules in each loc.; style with 3 stigmatic branches. Nechanism protandrous. Fruit a small capsule (20 $\mathrm{mm}$.) dehiscing by 3 valves; seeds packed with hairs (cotton) of testa: endosperm with fatty oil, small embryo; cf. G. arboreum. 'Trop. Africa, a woody shrub: G. barbadense, Trop. Amer., seeds with 'long-staple' hairs. Hibiscus sp. cult., epicalyx of numerous segments.

Thespesia populnea; evergreen tree of lit:oral forest in Tropics, also planted; foliage like Poplar, flowers like Gossypinm, but epicalyx reduced; carpels 5. stigmas fused in club-shaped mass. Capsule with silky seeds.

II. Bombaceae $(20 / 140)$, often separated from IIalvaceae by lack of some characters (no spinous pollen), and greater range in others (column-system more complex), seeds with little enclosperm but large enbryos.

Bombax malabaricum, Simal, Silk-Cotton Tree, Huge tree of alluvial ground, to $130 \mathrm{ft}$., buttressed trunk, soft wood, conical stem-prickles, large digitately. 5-7 lobed leaves, deciduous in hot season. Flowers (Feb.) before the leaves, large, scarlet, massive, gaudy, bee- and bird-pollinated, $4^{-6}$ in. Calyx leathery, splitting irregularly, with nectary-hairs of type. Androecium in 5 outer bundles of a dozen or more stout filaments $55 \mathrm{~mm}$, with twisted monothecic anthers, a few intermediate single filaments, and 5 inner (antisep.) branches each 2 -fid with 2 anthers only: no definite 'column'. Gynoecium 5-locular, with numerous ovules, style 5-lobed. Fruit a large capsule, 5-6 in.; seeds packed in dense mass of brownish silky hairs growing from the lining of the wall. Cotyledons much folded. 
Cf. B. insirme, a large deciduous tree of S. India and Burma: fowers 9 in. diam., similarly on old wood; petals scarlet, 5-6 in.; stamens $400-600$, with no definite column, 5 in. ; fruit capsule $4-8$ in.

Eriodondron anfractuosum (Ceibu pintandra); Large deciduous tree of Trop. Amer. and Mialay; planted in India and IBurma: stems with prickles, leaves digitate: flowers cream-white; androecium in 5 segments, simulating stamens, each with + twisted anthers; Gynoecium of 5 carpels; capsule, 3-5 in., packed with white silky hairs (liapok).

Adansonia digitata, Baobab of Trop. Africa, cult., to $75 \mathrm{ft}$. and $20-30 \mathrm{ft}$. diam.: trunk missive, watcr-storing, often hollow; to rooo yrs. old, enormous tap-root ( $100 \mathrm{ft}$. or more). Flowers large, white 6 in., with massive staminal column and crown of stamens. Fruits large $\left(8-\mathrm{r}_{2} \mathrm{in}\right.$.) pendulous, indehiscent, with large sceds in acid pulp, with woody fibres, eaten by natives and animals. Seeds $15 \mathrm{~mm}$., cmbryo large and much crumpled, endosperm reduced to a thin film.

Durio zibethinus, Doorian, Malay and cult. in S.; large fruits, to $12 \mathrm{in.}$ long, with soft prickles, inclehiscent, offensive smell; seeds with succulent arils as edible pulp.

Cullenia excelsa, a large tree of $\mathrm{W}$. Ghats in damp forest, young shoots and calyx with peltate scales. Flowers reddish-brown, apetalous, androecium in 5 filiform segments, each with about ro pairs of anther-clusters in longitudinal series; fruit, $3^{-4}$ in. diam., 5-locular, densely spinous, each loculus with $\mathrm{I}$ large seed with a fleshy white aril. Cotyledons massive.

11I. Sterculiaceae, $\left({ }_{4} 8 / 660\right)$ centred on Stirculia foelida of tropical coastforest: an empirical rangc of types distinguished from prececling by the normal dithecic ( 4 -loc.) anthers, the column rudimentary, decadent, or with alternative gynandrophore region. The valvate calyx persists, the stamens are few, the gynoecium fully syncarpous, or with the carpels united only in a common style-shaft, and breaking away in fruit to simulate apocarpous follicles. Extreme types may be apetalous and diclinous: the majority are fy-pollinated (accounting for the odour).

Pterospermum acerifolium, a tall evergreen tree of. hill-forest, and planted: flowers large, scented; sepals hairy, petals white, $5^{-6}$ in., all recurved (moth. pollinated): no column, but a gynandrophore-internode (20 $\mathrm{mm}$.), a group of 3 stamens opposite each petal, and 5 long antisep. staminodes ( 3 in.) and style-shaft; 5 carpels, antipet., 5 locular. Fruit a particularly massive woody capsule $(2-6$ in.), ripening the second season, dehiscing loculicidally, wall woody; $\frac{1}{2}$ in. thick; seeds numerous, with broad spinning-wing $30 \mathrm{~mm}$. long.

Theobroma Cacao, a small tree of S. Amer. (Cocoa), cult.; flowering spurs on old wood: flowers small and insignificant, I $5 \mathrm{~mm}$. over all, 5-parted; column rudimentary, 5 dithecic stamens with anthers sheltered in hooded tips of petals, alternating with 5 slender pointed 'staminodes'. Fruit a large indehiscent capsule (8-9 in.), with many large irregular seeds: endosperm scanty, large cotyledons (cocoa-nibs) store fat.

Sterculia urens, a large tree of dry deciduous forest with conspicuous silvery bark. Flowers in crowded panicles with tomentum of glandular hairs, apetalous; Staminate flower with 20 stamens on a short internode. Hermaphrodite flowers (few) with short gynandrophore and $4-5$ carpels fused in style-shaft only. Fruit of ovoid radiating follicular segments, 3 in., red internally, with 'stinging' bristles : seeds $3^{-6}$ per pod.

S. villosa, a common tree in dry deciduous forest; flowers yellow in clustered dropping panicles on leafless branches: majority of flowers staminate only: caly $\mathrm{x}$ campanulate, hairy; anthers ro, on short internode. Follicular segments $2-5$, coriaceous 3 in., red, with stiff hairs and several blue-black seeds (like Paeonia pods).

S. (= Plirggola) alata, a very large tree of moist evergreen forest: planted: calyx rusty-tomentose, gamosep. and campanulate: stamens $\mathbf{1}_{5}$, on long internode. 
Follicular segments, $1-5$, huge subglobose pods, 4 in., stalked $3-4$ in., seeds in 2 rows, large and winged, $2 \frac{1}{2} \mathrm{in}$.

S. (= Firmiana) colorata, a large soft-wooded tree of Sub-Himalya, E., and S. India; bright-red inflorescences of flowers with stellate tomentum: calyx 1 in. long, funnel-shaped, with 5 teeth: gynandrophore long and projecting: stamens small, carpels 5. In fruit the follicular segments become membranous, leafy, coloured pink, and break away with each 2 marginal seeds (in simulation of theoretical carpel).

S. foitida, a deciduous tree with digitate leaves, flowers on bare branches, very offensive; follicular segments as woody pods, bright-red, many-seeded.

Heritiera littoralis, widely distributed in tropical sea-coast forest, gregarious and evergreen: panicles of small flowers, apetalous, mostly staminate only, and much reduced. Leaves coriaceous, silvery underneath. Fruits as stout, strongly keeled, I-seeded nuts, exalbuminous.

H. Fomes, Sundri, gregarious cvergreen tree characteristic of Sundribans, on alluvium behind Mangrove zone: roots with 'tent-peg' pneumatophores: caly $x_{4-5}$ toothed; staminate flower witl rudiment of gynoccium shows the limit of reduction: stamens $4-5$ : gynoecium of 5 carpels, separating as woody nuts, slightly lieeled, floating at the highest tide-levels.

Cf. H. macrophylla, a large tree of Burma, inland, fruits globose with a 'beak'portion and no keel. H. Papilio of W. Ghats in evergreen forest, carpels with a broad membranous wing, strongly veined.

IV. Tiliaceae $(35 / 350)$. Forest-trees with flowers of mediocre Cistifloral habit, but little special modification-sepals valvate, anthers dithecic, no column-but stamens often in 'bundles', ovary syncarpous. Fruit tending to indehiscent nut or drupe. Cf. Tilia, indig., and Sparmamia, Hort.

Corchorus capsularis. Jute (with $C$. ditorius), herbaceous annual, indig. to China, cult Bengal and Assam, valuable fibre (Gunny); S-r 2 ft., Flowers $1-3$, opposite the leares, small, yellow, I $2 \mathrm{~mm}$. diam., pentamerous; stamens many, on a short column; Fruit a sub-globose, longitudinally-ridged capsule, many-seecled; elongated and beaked in $C$. olitorius.

Pentace burmanica, Thitka, large evergreen tree of Hill-forest, Burma; Stamens in 5 bundles of 4-7 each, alternating with slender staminodes. Capsule over $\mathbf{I}$ in. long, indehiscent, with 5 broad longitudinal wings, I-seeded.

Berrya Ammonilla, a tall deciduous tree of Burma, \&c.; Flowers white, $\frac{1}{2}$ in., with numerous stamens, no staminodes, ovary $3^{-4}$ locular. Fruit a small capsule with several seeds and 3 pairs of horizontally extending wing-segments, $\mathrm{I}$ in. long.

Grewia oppositifolia, a common deciduous tree of W. Himalya, planted; stamens indefinite on a slight internode, Fruit a drupe, deeply $2-4$ lobed with same number of pyrenae, black when ripe; a large genus, $30 \mathrm{sp}$. Indian.

Elaeocarpus Ganitrus, typical of a large genus (1 23, Indian 26) of evergreen trees of moist tropical forest, flowers small with fringed petals: stamens 25-35, ovary 5-locular: Fruit a globose drupe, $x$ in. diam. with characteristic solid sclerocarp, grooved and corrugated, commonly I-seeded. E. lancenefolius, a large tree common at Darjeeling. 
DISCIFLORAE (Gin.. Plant. 1862), a convenient assemblage of largely tree-phyla, cluaracterized by a cucyclic type of floral organization, in which reduction of the androeciun to a limit of $5+5 \mathrm{in}$ whorled alternation is typically associated with the specialization of a receptacular disc-nectary, usually indicating entomophily by the agency of insects with short-proboscides (primarily).

'The foral organizition thus normally presents a quincuncial calyx, a whorled pentamerous corolla, two whorls of stamens, and a single whor of 5 carpels: the alternation is not necessarily concurrent throughout the system, and the 5 carpels are typically antipetalous. The gynoecium may reduce to fewer carpels $(4,3,2)$, rarely increased by irregularity, and the output of ovules may vary within wide limits. The eucyclic type appears as the symmetrical and complete construction formerly abstracted empirically by older morphologists as a key to floral evolution.

The construction may present further spccialization for insects of higher grade, as by zygomorphy (median or oblique), or by attempts at tubular organization in calyx or androecium. Reduction may occur in phases of tetramery, irregularity in hexamery, dicliny and dioecism, apetaly, isostemony, and the limitation of gynoecial output, with a single ov'ule setting a single seed per flower as the end-term. All phases of fruit-claboration obtain, from many-seeded dehiscent capsules to indehiscent berries, nuts, and drupes. The families have been sorted out largely by special fentures of somatic organization and by special types of fruit-elaboration.

In absence of any other very distinctive characters it has become traditional to isolate two empirical series, according to the orientation of the residual orules in the reduced orary, as Geraniales (Geranium-type), ovules pendulous with raphe internal, and Sapindales (Horse-Chestnut-type), with raphe external. More herbaceous families (Oxalidaceae, Linaceae, Geraniaceae, Tropaeolaceae, Balsaminaceae) in cultivation (Hort.) are omitted, and the diclinous Euphorbiaceae are taken in their old position with the apetalous families as a matter of convenience (p. $3^{6}$ ).

Also note, the characteristic disc-nectary (discus) may be intri-staminal, extrastaminal, generally receptacular, or superseded by other mechanism (Pelargonium, Tropacolum, Impatiens), and there is no very convincing evidence that many of the families conventionally associated express any actual derivation from the typical cucyclic construction after all (Acsculus, Accr, Tropacolum), but may represent end-terms of a general convergence to a minimum of working-mechanism of similar jarts.

I. Erythroxylaceae (2/194) isolated for Erythroxylon; cf. E. coca of S. Amer. Erythroxylon monogynum a small tree of dry districts, S. India; leaves, I in., simple; flowers small, 6 mm., axillary; pentamerous with $5+5$ stamens united below in a staminal tube, and 3 carpels: Fruit a scarlet drupe, $\mathbf{I}$ loculus fertile with I seed.

II. Malpighiaceae (54/500) woody shrubs, largely lianoid, based on Malfighia of Tropical America: flowers pentamerous, commonly zygomorphic, stamens $5+5$, carpels 3 .

Hiptage Madablota, a straggling climbing shrub of forest-ravines: flowers complex, with stemotribal presentation, obliquely zygomorphic in plane of sep. 3 (giving odd petal at back), $r$ in. diam.; stamens 10 , the front one larger than the others; carjels 3 : Fruit an angular nut, $\mathbf{I}$-seeded, with 3 divergent wings, the middle one longer, 2 in.

III. Rutaceae (III/800) a key-group (cf. Ruta) with typically full eucyclic organization, distinguished by oil-glands in the leaves: flowers range to tetramery, with irregrularities of construction in Auranticae-section: cf.-

Choisya ternata (Hort.), evergreen shrub of Mlts. of Mexico, leaves opposite, 3.lobed, glossy and aromatic: terminal corymbose panicles of white flowers, I in. diam.; petals $5-8$, stamens ro-15; the filaments massive, white, making close- 
contact around the ovary, restricting lateral access to the intrastaminal disc (tending to tubc-protection of secretion).

Citrus medica, a hill-shrub, cultivated in vars, as Citron, Lcmon, Limes; stamens $25-55$, in single palisade of strap-shaped groups; carpels 9 -1 I ; flowering and fruiting throughout the year.

C. Aurantium, Orange, of E. Himalya, cult. in vars., stamens $15-30$, carpels I O-13, often a reduced second whorl: moth-pollinated.

C. decumona, Grape-fruit, Shaddock; flowers larger, petals recurved; stamens about 40 , in tubular palisade, ro $\mathrm{mm}$.; carpels $8-16$ : fruit to $8 \mathrm{in}$. diam. and 5-6 lb.

Aegle Marmelos, Bael-trec, a small tree of dry deciduous forest, to ft., with spinous branches, much cult. Flowers greenish-white, I in. diam., fragrant. Stamens indef, carpels ro; liruit an Orange-type, $4_{-5}^{-5}$ in. diam., with yellow hard woody rind, and numerous scels in orange-coloured sweet aromatic pulp: token by animals, monkeys, deer, sc.

IV. Simarubaceae $(27 / 125)$ based on Simaruba a medicinal plant of W. Indies, for Discifloral forms in which the carpels are united in the style-shaft, but break away in the fruit-stage, and so appear 'apocarpous'. No oil-ducts or glands; the flowers more or less reduced and diclinous.

Ailanthus excelsa, a large tree of deciduous forest, also cult., leaves pinnate (1 2 pairs), I-3 ft. Staminate flower with ro stamens only: carpellary flower of 5 carpels. maturing fruit as $\mathbf{I}-5$ flat red samaras, $2 \frac{1}{2} \mathrm{in}$.; seed centred and a slight spiral twist at the ends.

Cf. A. glandulosa, China, cult., dioccious; samaras 2 in., red when mature: leaflets with glanclular teeth near the base: spreading by root-suckers.

V. Burseraceae ( $16 / 320$ ), based on Anserican forms of Bursera for a group of tropical trees with resin-ducts: flowers small and of considerable range: $\mathrm{cf}$. Balsamodendron Myrha of Arabia, \&c.

Boswellia serrata, Salai, a fairly large deciduous tree, common and gregarious on dry hills, leafless in hot season: Flowers small, 5 mm., green, on the bare branches: stamens $\bar{j}+5$, disc intrastaminal: orary 3 -locular, fruit dehiscing by 3 -valved sarcocarp, with 3 pyrenae.

Garuga pinnata, a large deciduous tree, associated with Sal and Teak; flowers comparatively large, in yellowish panicles, with marked perigynous cup: stamens $5+5$, ovaiy $4-6$ locular, each 2 ovules: Fruil a drupe with $2-4$ tubercled pyrenae persisting in soil $\mathrm{I}-2$ years.

VI. Meliaceae (40/600), a great order of tropical forest-trees, with panicled inflorescences of small Discifloral flowers, normally distinguished by the characteristic utilization of a staminal tube, as practically a gamophyllous mechanism protecting the grnoecium and ultimately also controlling the nectary: petals tend to become superfluous. Fruits characteristically capsular, with winged seeds, but commonly ranging to drupes with reduced outpul of seeds: in one important genus at least there is no staminal tube.

Swietenia Mahagoni, Spanish Malıogany, a great tree of Trop. Amer., leaves pinnate, panicles of small flowers, $7 \mathrm{~mm}$.; staminal tube, $3 \mathrm{~mm}$., urceolate, with Io teeth alternating with the anthers. Fruit a woody capsule, 3 in., 5-valved, witl numerous winged secds. Cf. larger fruit of $S$. macrophyllla, 5-6 in., falling to pieces, seeds winged, 3 in.

Walsura villosa, Gyobo, common evergreen tree of Burma: flowers, small, $5 \mathrm{~mm}$., with filaments gamophyllous below, broad and convergent above, seed with fleshy aril in a pointed berry. W. robusta, similar, filaments free.

Azadirachta indica, Neem, cult. everywhere, monotypic; leaves pinnate, evergreen; flowers in large panicles, small, white, ro mm. diam.; staminal tube, $5 \mathrm{~mm}$., narrow; with ro teeth superposed to ro anthers: disc inside the tube; carpels 3 , each 2 ovules; Fruit a drupe, $\frac{3}{4}$ in., I-seeded. 
Mclia Azedarach, 'Persian Lilac', a deciduous tree in general cult. Leaves $2-3$ limes pinnate. Flowers $12 \mathrm{~mm}$. diam, petals white, staminal tube, $6 \mathrm{~mm}$., narrow, violet-jurple; anthers 10, altcrnating with paired looth-processes of tube; Gynoecium $3^{-6}$ locular, 2 ovules in each loc.; Fruit a small drupe with 5 -seeded bon' : clerocal'), giving $1-4$ seedlings.

Carapa moluceensis (= Nylocarpus), a timber-tree of the Sundribans and Mangrove-formation, 30-50 $\mathrm{ft}$., with pneumatophores; evergreen, leaves pinnate, panicles of few small reducel flowers, tetramerous, with urceolate staminal tube and $S$ teeth altemating with the anthers. Ovary 4-loc., 2-S ovules in each loc.; fruit 3-; in. diam., as a massive subsplerical woody capsule, deliscing by 4 valves, and shedling large angular seeds ( $1-2$ in.), which float or germinate immediately; cotylectuns store starch, gemination hypogeal.

Soymida febrifuga, a large deciduous tree of dry forest of S. India, \&c.; leares pinmate: flowers small, greenish-white in terminal panicles; staminal tube 10-cleft, with 2 tecth on either side of the anthers. Ovary 5 -locular; fruit a capsule, I-2 in., dehiscing by is woody valves: seeds flat, winged at both ends.

Chukrasia tabularis, a large tree of moist hill-forest (Clittagong): flowers white, $\frac{1}{2}$ in. long; staminal tube cylindrical with 10 anthers on the rim. Ovary 3-locular ; fruit a capsule, $1 \frac{1}{2} \mathrm{in}$, dehiscing by 3 woody valves; seeds broadly winged at one end.

Cedrela Toona (= Thona cilinfa) Toon-tree, a large deciduous tree of SubIlimalya and moist hill-forest, cult.; Flowers small, white, in loosely panicled sistems; there is no true staminal tube, but a receptacular extension as nectarypockets at the base of the flower (antisep.), between orange lobes of the 'disc': stamens ; only (antisep.). Fruit a typical 5-valved capsule with many close-packed sceds. $\frac{1}{2} \mathrm{in}$. long, wingred at both ends and spinning freely. Cf. C. serratu, with i) stamens and 5 staminodes: C. odorata of $\mathrm{W}$. Indies, seeds winged at distal end only:

Chloroxylon Swietenia, Satinwood; valuable timber-tree of Central and $S$. India. clistinguished from the preceding by absence of staminal tube, and with gland-dotted leires. Disc ro-lobed, intrastaminal; ovary 3-locular; Fruit a typical capsule dtehiscing loculicidally by 3 valves as in Chutrasia, will winged seeds. IIith pinnate foliage, small flowers in panicles, generalized eucyclic flower and capsular fruit with winged secds common to many Neliaceae, but now referred to Rutaceac. 
SAPINDALES (Engler) include families of tree-habit, in which the full eucyclic floral construction is rarely expressed. Reduction-variants of all grades occur, and may have had a wholly distinct origin. The fruits range from debiscent capsules to indehiscent nuts and fleshy drupes: in one fumily the limit of gynoecia] reduction to one ovule per ovary, setting a $\mathbf{I}$-seeded clrupe or nut, is constant. 'The Rhamnales, a section of minor significance, with the androecium reduced to isostenuony, and the stamens superposed to the petals, is added as a matter of convenience.

Aesculus indica, a fine Horse-chestnut of NIT. Himalya, very similar to the common form, affords a typical case: a large deciduous tree (100 ft.), in moist shady ravines, with lecussate digitate foliage-leaves and terminal pyramidal pranicles (12-15 in.) of white zygomorphic flowers (petals with yellow splash turning crimson). in lateral monochasia; zygomorphy oblique in plane of sej. 4; corolla of 4 petals, androecium of 7 staniens, and ovary of 3 carpels. Fruit a dehiscent massive capsule ( 2 in.), without spines; sceds $I_{-2}$ in, with massive cotyledons storing starch. On the strength of the peculiar androecium and the decussate digitate leaves, the type is often separated as Hippocastanaceae (including Pavia).

Sapindaceae (I $\mathrm{S} / \mathrm{I} 050$ ), a large and cluaracteristic order of tropical trees, more generalized than Aesculus, leaves commonly spirally arranged, pinnate or simple, but also of wide range in floral reduction (following dicliny and apetaly). The fruits range from dehiscent capsules to individualized drupes; the 3-carpelled gynoecium is a general feature, and the stamens are commonly 8 (or less than ro). Genera have been grouped around Sapindus; cf. S. Saponaria of S. Anerica, as yielding 'Soap Nuts' of economic significance: cf. as typical :-

Xanthoceras sorbifolia, China (Hort.), with deciduous pinnate foliage, spirally arranged: flowers in erect terminal systems, diclinous; petals white (with yellow turning pink); staminate flower with 8 functional stamens; disc prominent with 5 orange-yellow horn-like nectary-lobes: carpellary flower with 3 carpels, syncarpous, and several orules: fruit a large woody capsule, dehiscent loculicidally?

Sapindus laurifolius, Soap Nut of S. India, a large evergreen tree of dry regions, much planted: leaves pinnate, 3 pairs of large leaflets. Flowers staminate, with a few perfect: sepals 5, petals $4-5$, stamens 8 , ovary 3 -lobed. In fruit the ovary lobes separate as 2-3 small indehiscent drupe-portions, readily detached: the seeds contain saponins.

S. detergens (= Mukorossi), with $5^{-10}$ pairs of leaflets, is the representative species in $\mathrm{NIV}$. Himalya, cult. for soap: Drupes usually solitary $(1-2)$, the others rudimentary, $\frac{3}{4}$ in.

Nephelium Litchi, evergreen tree of S. China, cult. for fruit; Flowers in large panicles, few, hermaphrodite, small, apetalous, and irregular in construction: calyx $4-8$ cleft, gamosepalous; petals usually wanting; stamens $5^{-10}$, ovary $2-$. lobed, each loculus with I ovule. In fruit (edible) I or more lobes enlarge to sharply tubercled globose structures ( $\mathrm{I}$ in. diam.) with I seed enclosed in a white pulpy aril.

N. Longana, a timber-tree of W. Ghats and Ceylon, essentially similar, but fruit $\frac{3}{4}$ in., nearly smooth, also with sweet edible aril.

Dodonaea viscosa, a small tree $(20 \mathrm{ft}$.), gregarious as scrub in dry tracts of Central India, \&c.; young branches exude yellow resin: flowers panicled. small, $5 \mathrm{~mm}$. greenish-yellow; apetalous, with 8 -ro large anthers; ovary $3-4$ locular, 2 ovules in each loculus. The fruit is a thin-walled capsule, $2-4$ valved, $\frac{3}{4}$ in. over all, each valve with a broad wing-extension.

Scleichera trijuga, a large tree of mixed diy deciduous forest, often gregarious, the best for Lac-insect. Leaves conspicuously of 3 pairs of leaflets. Flowers in drooping panicles $(3-5$ in.), largely staminate only and apetalous, or 
partially dioecious, $5 \mathrm{~mm}$. Calyx minute with $5^{-6}$ teeth, petals wanting; stamens 6-8, divergent: disc with way lobes; ovary with $3-4$ loculi, basal placentation, and I orule per loculus. Fruit globose, 1 in. long, I-2 seeded, indehiscent: sced with pulpy (edible) aril, storing oil.

As examples of smaller families, based on tree-forms familiar in the N. Temp). forest, and presenting representative species, cf.--

Ilex dipyrona (Aquifoliaceae), a type very similar to Ilex Aquifolium, in valleys of NW. Himalya ; flowers grcenish-white, diclinous, tetramerous, but usually 2 carpels only, orules i per loculus, pendulous with raphe external, hence fruit usually with z pyrente.

Euonymus Hamiltonianus (Celastraceae), also a typical Euouynus, as a small tree of outer Himalya : tetramerous type of construction, flowers $8 \mathrm{~mm}$. diam.: disc bioall over centre of flower. Fruit deeply 4-lobed, and seeds with crimson arils.

Accr pictum (= cullratum) Aceraceae, a typical Naple of NIV. Himalya; a large deciduous tree, with palmate very acutely lobed leaves and early-flowering corymbose panicles. In fruit the 2 carpel-wings diverge widely in the same line, and turn bright red.

Cf. A. caisium, a large deciduous tree of W. Himalya; fruit-wings only slightly divergent; also as representative species, $A$. Campbelli of E. Himalya, flowers in narrow panicles, and carpel-wings diverging 1 in. with broad rounded ends.

Anacardiaceae (58/500), based on Anacardium with its peculiar fruit. A great group of important tropical trees (cf. Rhus of $\mathrm{N}$. Temp.) segregated by the limiting reduction of the gynoecium of $5^{-3}$ carpels to output of one usually pendulous ovule only. The flowers are of typical small Discifloral habit, greenish-white, panicled, fy-pollinated; the stamens 10-5 (or reduced), and the carpels practically free, or traced only in the stigma-lobes. The seeds are exalbuminous and the cotyledons store falty oil. Acrid juice, lacquer, and resin are characteristic products.

Anacardium occidentale of $\mathrm{S}$. Amer., cult. (Cashew Nut): Panicles of small yellow-pink flowers; petals linear, stamens ro, the one over sepal no. I longer and fertile, the others reduced and sterile. Fruit a kidney-shaped drupe ( $r$ in.) on an orange or crimson enlarged receptacle ('hypocarp'), 2-3 in., èdible, and dispersed by birds. Pericarp with acrid blistering oil.

Semecarpus Anacardium, Narking Nut: panicles of small flowers; drupe, 1 in., purple-black with orange hypocarp (edible): pericarp with acrid juice.

Mangifera indica, NIango, indig. to Burma and moist hill-forest, cult. in vars, and grafted: panicles of greenish-white flowers, $5 \mathrm{~mm}$; majority staminate, few hermaphrodite, with only I fertile stamen, and 4 others reduced and sterile. Drupe 2-6 in., yellow, with one great seed in fibrous sclerocarp; cotyledons with fat-storage, germination hypogeal.

Buchanania latifolia, conspicuous small tree, $50 \mathrm{ft}$., of deciduous forest with Sal, and in Iurma: characteristic faceted bark: flowers in tomentose panicles, small, $5 \mathrm{~mm}$., greenish-white; stamens ro, carpels 5 , one fertile and others as rudiments. Fruit a drupe, $\frac{1}{2}$ in., edible, with bony sclerocarp.

Spondias mangifera, a large tree of deciduous forest, and planted; fruit large in manner of Mango, edible and taken by deer.

Melanorrhoea usitata, characteristic large deciduous tree of Eng forest (Black lacquer): in fruit the petals grow to 5 'wings', 2-4 in. long, pink when growing and suggesting flowers, spinning freely. Fruit a dry nut on a distinct 'stalk' internode.

Swintonia floribunda, conspicuous tree in hill-forest (Chittagong), of similar habit in fruit; Nut elongated, not 'stalked', with 5 petal spinning-wings, purple, ultumately 2 in. long.

Odına Wodicr, a large spreading tree of deciduous forest of India (with Sal) and Burma, cult.; Flowers in feathery whitish panicles, small, monoecious; carpellary flowers with sterile stamens. Drupe $\frac{1}{2}$ in., taken by birds. 
Pistachia integorrima, deciduous tree of dry slopes of WV. Himalya, with characteristic leaf-galls $6-7$ in. long. Flowers small, clioecious; Drupe $\frac{1}{4}$ in.

Rhamnaceae ( $45 / 500)$ based on European Rhamnus (Buckthorn); cf.-

Zizyphus Jujuba, a spinous tree, largely cult. for fruit: flowers small, greenish-yellow; ovary sunk in receptacle, 2 -locular; fruit a drupe, $\frac{3}{4} \mathrm{in}$. long (to $\mathbf{I} \frac{1}{2}$ in, cult.), with furrowed stone, 2 -sceded and giving 2 seedlings.

Ampelideao (Vitaceae, I $1 /+50$ ) include liana-forms as litis, Wild Vines, 400 sp., c., :-

Vitis vinifera indig. to NW. Himalya and W. Asia, cult.; a large woody climber with inflorescence-tendrils: flowers small, green, panicled, petals cohering distally and shed; stamens 5 antipet., free : carpels 2 , ovules 2 (3) per loculus: berry 3-5 seeded, endosperm solid with thick walls.

Leca, a genus of erect shrubs, no tendrils, flowers with greater range, stamens uniting with petal-bases in a staminal tube. I. umbraculifera in valleys, Sikkim, $50 \mathrm{ft}$, with thick trunk. 
The LEGUMINOSAE ( $\left.429^{\prime} / 2000\right)$ commonly approached througl the herbaceous upes of Bean and Pea of $\mathrm{N}$. 'l'emp. cultivation, represent a vast series of polypetalous apocarpous pliyla, in which the gynoecium is restricted to the limit of one carpel only, of rery typical megasporophyll nature, giving rise normally to a 'pod'-fruit or legume. With this reservation the floral mechanism, based on a limiting expression of pentamerous eucyclic construction, may be further complicated in terms of the zygomorphy more familiar in the Papilionaceous type, but may also present extended range of specialization and reduction in the more distinctly tropical series of the Caesalpineac. On the other hand, the section Mimoseae presents a similar gynoecial reduction in a phylum of very divergent nature; the three sections being in fact sufficiently distinct to be regarded as inclependent families, convergent in this limiting reduction of an archaic apocarpous phase, and still holding their own in competition with syncarpous types, as in practice a single ovary-construction per flower has been attained.

I. The Papilionaceae (308 gen.), following the general type of the Pea and Bean in floral organization, include many fine forest-trees; generic types may be isolated by special features of the fruiting-stage, and the characters of the foliageleaves.

Butea frondosa, Dhak, a deciduous tree of open grass-lands, flowering (n) masse on the hare stems. Leaves trifoliate, leaflets coriaceous, 4-6 in. broad: Flowers orange-red or scarlet, 2 in.; standard recurved, lieel boldly arched, stamens $9+\mathrm{I}$; pod 5 in. $(4-8)$. flat, with one flat seed at base, and the distal part acting as spinning-wing, 4 in.

B. suferla a gigantic liana-form of S. India; stem to 8 in. diam., flowers larger, bright orange.

Dalbergia Sissoo, Shisham; a large deciduous tree of Sub-Himalya, \&c., often gregarjous on alluvial ground, much planted; Flowers small, $7 \mathrm{~mm}$., yellowish white. in short axillary panicles. Stamens 9 , pod linear lanceolate, $2-2 \frac{1}{2}$ in., I-3 seeded, light, flat, indehiscent, wind-distributed and floating on flood-water.

Cf. D. latifolia, Rosewood, a large tree of deciduous forests: Larger pinnate leares, inflorescences, and pods, of same type.

D. Mclanoxylon of W. Africa, naturalized: D. Olivieri in Eng forest.

Pterocarpus, also a valuable timber genus, with representative species, distinguished by broadly winged, one-seeded indehiscent fruits:-

$P$. indicus, Burmese sea-shore Padauk; pod flat and nearly circular, $1-2$ in. diam. ;

$P$. dalbergioides, Andaman Red Wood, evergreen.

P. macrocarpus, deciduous, Inland Padauk of Eng Forest ; pods $2 \frac{1}{2}-3 \mathrm{in}$. cliam.;

I’. san'alimus, Red Sanders, of Cuddapah, pods $\mathrm{I} \frac{1}{2}$ in. :

P. Marsupium, Bija Sal, a large tree (roo ft.) of deciduous forest: Kino. Flowers, yellow, $18 \mathrm{~mm}$., stamens 10 , tube slit down in med. plane; Pods $1 \frac{1}{2}-2$ in., 1 - 2 seeded.

Pongamia glabra of tidal coast-forest: flowers typical, Pea-lıke, $20 \mathrm{~mm}$.; post. stamen free at base only: pod xerophytic, massive leathery, 2 in. long, and I broad, 12 secded, germination bypogeal.

Cr. also:- Sofhora japonica (Hort.) with to stamens, all free: Colutca (Hort.) with bladder-pods: Indigofira linctoria, Indigo, flowers small, in purple racemes; stamens 9+ I, pod simple; a shrub often cult. as amnual: Mucuna, pods $2-3$ in., with irritant bristles: Desmodium gyrans, Telegraph Plant, herbaceous trifoliate leaves, 2 lateral small pinnules show automatic movements, end-leaflet nyctitropic only: Aeschynomene aspera, Sola, a water-plant, with stem 2-3 in. diam. and soft pith-like white wood. Ongeinia dalbergioides, common in Sal forest, and cult.; 
flowers in clusters on old twigs, pods slender with slight constriction between the seeds.

II. Caesalpineae (9I/Iroo), a scries in which the Pea-type of flower is infrequent. Examples of extreme zygomorphy occur, but practical actinomorphy may be retained, or parts may be further reduced; cf. as available:-

Cercis Siliquastrum, Judas Trec, of S. Europe: Flowers on bare branches in clusters on spur-shoots before the leaves, pink and Pea-like, $\frac{3}{4}$ in.; stamens all free; a definite perigynous receptacle as nectary-cup, the standard-petal enclosed within the wings, as these are inside the keel. Pods flat, 3-4 in., hanging from the branches.

Haematoxylon campechianum, Logwood ; small trce of W. Indies, cult.; Flowers actinomorphic, $8 \mathrm{~mm}$; petals cqual, yellow; stamens $5+5$, but one carpel only, and the fruit one-seeded: in some respects possibly the most elementary form of the group.

Hardwickia binata, Anjan; a large gregarious timber-tree of dry deciduous forest of S. India, deep-rooted; Leaflets 2 only; $\mathrm{I}-2 \mathrm{in}$. long, with terminal pointed rudiment: Flowers small, greenish-yellow, I $5 \mathrm{~mm}$., in lax racemes, afetalous; sep. 5 , stamens $5+5$, one carpel; fruit a flat pod, $2 \frac{1}{2} \mathrm{in}$., indehiscent with one seed at distal end, spinning-type : the limit of simple reduction. As extreme cases, cf. :-

Cassia Fistula, a tree of deciduous forest, and commonly cult.; leares pinnate; with pendulous racemes of yellow flowers (suggesting Laburmum): stamens differentiated, 3 long anterior dehiscing by slits, 4 with shorter filaments and dehiscing by pores, 3 posterior minute and sterile. Pod cylindrical, large, black, $\mathbf{I}-\mathbf{2} \mathrm{ft}$., with seeds in black resinous pulp, medicinal and economic; animal-dispersed.

C. auriculata a shrub on dry stony soils gives tamins.

Poinciana regia, Gold Moluur Tree. African, cult., with erect show! panicles of scarlet flowers; pocls flat, $\mathrm{I}-2 \mathrm{ft}$.

Tamarindus indica, a fine tree of C. Africa, naturalized and cult.; Lax racemes of $10-15$ flowers; 3 post. petals only functional, 2 ant. minute; 3 jost. stamens large and curved forwards, others as restigia only. Pods as thick liuslis with brown acid pulp, fibres, and small brown seeds.

Amherstia nobilis, evergreen tree of S. Burma, cult.; leaves hang vertically when young. Inflorescences as pendulous racemes, many flowered; prophylls large and scarlet, 2 posterior sepals give a hooded segment, others simple; 3 post. petals, of which the median is a flag-segment with broad waved lamina with crimson and yellow blotch at end, 2 anterjor as rudiments. Stamens $9+1$; med. post. stamen reduced; 5 anterior long, and 4 short: Perigynous receptacle extended to $\mathrm{mm}$. to a narrow nectary-tube; loney-bird pollinated. Pod flat and linear, $7 \mathrm{in}$.

Bauhinia Vahlii, a gigantic liana-form, destructive to Sal, Ec.: stem to $100 \mathrm{ft}$. long, and $\mathrm{I}-2 \mathrm{ft}$. diam., growing $50 \mathrm{ft}$. a year, with anomalous thickening. Leaves to I 8 in., 'cleft' $\frac{1}{3}$ down: Flowers creamy-white, 5 petals and 3 fertile stamens; petals hairy, $1 \frac{1}{2}$ in. long. Pod $9-18$ in., long, broad and flat, hairy; woody and bursting explosively.

B. variegata, a middle-sized tree of dry deciduous and hill-forest, cult. ; Flowers large and showy, fragrant, white and pink: standard-petal darker or variegated, conspicuous, with 5 functional stamens. Pods long and slencler.

III. Mimoseae (30/1000): a wholly clistinct type of floral organization, familiar in Acacia dealbata (Mimosa), the Australian Silver Wattle. Foliage bipinnate, evergreen; inflorescence as panicles of small globular capitula, $8 \mathrm{~mm}$., fragrant; flowers not all perfect, minute, with a dense cycle of 30 stamens, slender style, reduced valvate sepals and gamophyllous petals; actinomorphic, pollen in packets. Fruit a pod $(2-3$ in.) dehiscent, seeds non-endospermic. Elementary forms have larger flowers on a similar plan in more racemose spikes.

Prosopis spicigera, Jhand: a stunted thorny tree, gregarious in dry tracts of Punjab, scc., persisting by deep root. Flowers in slender spikes; stamens 10 , anthers 
with apical 'gland'. Pod with coriaceous liusk, indehiscent, 5-10 in., seeds in sweetish pulp with contracted portions.

Entada scandons, a huge liana-form of Tropical sea-coast and hills: flowers pale-yellow, in crowded slender spikes. Stamens io, with 'gland'. Pod immense, $2-+\mathrm{ft}$., wool, $10-30$ seeded, separating 'Cocci' from rim-framework, each with Iflat seed, orhicular, polished, 2 in. diam.

Xylia dolabriformis, Pyingado, gregarious in deciduous forest, with Teak in Buma : Flowers pale-yellow, in long-stalked sub-globose heads, $20 \mathrm{~mm}$. diam.: Pod thick, woody, xerophytic, $4^{-6}$ in. long, with characteristic curved valves, very explosiwe, 6-10 seeds.

Acacia arabica, Babul, a large tree of dry regions, deserts of Rajputana, and cult., gregarious. thorny, and often stunted. All parts used, wood exudes gum: Flowers golden-ydlow, in globose heads, $\frac{1}{2}$ in. diam.: Pod moniliform, flat, 3 in., with marked constrictions between the seeds, and covered with grey tomentum; taken by cattle.

Cf. A. Senegezl, African sp. also cult. for Gum Arabic: A. Verck of Sudan.

A. Catechu, Khair, middle-sized tree of dry deciduous forest and sides of strcams: nowers in pale-jellow cylindrical spikes, 2-3 in. long; Pods thin, brown, and dehiscent, $2-+$ in.: 'Cutch' of tannins from wood-chips.

Albizzia procera, White Sinis, a large deciduous tree, conspicuous near riverbanks, also cult. : Flowers large, ro $\mathrm{mm}$, with delicate stamens. Pod flat, brown, strap-shaped, $4^{-8}$ in.: Young leaves with white tomentum.

A. odoratissima, Black Siris, a large tree, common in mixed forest, leaves dark-green, leaflets 10-25. Flowers $10 \mathrm{~mm}$., in panicled corymbs, fragrant. Pod 6-S in., smooth and flat, reddish-brown.

A. Lobbek, Siris, common and cult., avenues. Flower $\mathbf{I}$ in. long, in heads, white and fragrant. I'od, 8-I 2 in., thin and dehiscent, straw-coloured, rattling when dry in hot season.

Pithecolobium dulce, Karkapilly, spinous hedge-plant from Mexico: Flowers white, in small globose heads on long racemes. Pod $4^{-5}$ in., coiled, red and succulent hu.k; seeds in spongy edible pulp.

P. Saman, Rain Tree of S. Ameica in damp situations and swamps, Burma.

Mimosa pudica, Sensitive Plant (Hort.), a spincus shrub, as weed from S. America: flowers in globular pale-violet heads, $20 \mathrm{~mm}$. diam., Fruit-pods small, I in., constricted, spinous.

Rosaceae include representatives in Hill-forest, of such types as Spiraca, Rubus, Rosu, Cydoniu, Eriobolry'a, Pyrus, Cralaegus, Prunus (P. Amy'gdalus, Almond; $P$. persica, Peach; P. Puddum of Himalya, \&c. gives timber). Cf. also Cotoneaster Simonsii (Hort.) of Khasia Hills.

Saxifragaceae similarly afford representative species of flowering shrubs as Philadelphus, Deutzia, Ribes, \&ec. (Hort.). 
CALYCIFLORAL FAMILIES, originally' isolated by the 'calyx'-like character of a receptacular extension, commonly giving rise to phenomena of the 'inferior' ovary, and extended to cover other cases of special receptacular develop)ments (cf. Rosales, Lythraceae, Cactacene, Passifloraceac), are now seen to be a wholly empirical collection of highly specialized floral constructions in which the inferion ovary remains the most readily observed feature of the floral organization, also affecting the subsequent formation of the fiuit. In such cases other special features previously emphasized acquire a subsidiary significance, as apocarpy (Rosaceae, Leguminosae), indefinite androecium (Myrtales), even spiral construction of indefinic perianth (Cactaceac), eucycly (Combretaceae), meiocycly (Umbelliferae). Similarly all stages of reduction (tetramery, dicliny, apetaly) may also obtain in deteriorated mechanisms, and the fruiting-stage may present the full range of variety, from dehiscent carpels and capsules to one-seeded drupes, nuts and achenes.

So long as the exact relation of these isolated families to other series remains: a matter of mere speculation, the section-heading is provisionally retained as the most generally convenient arrangement (Gin. Plant., I 862).

I. Myrtaceae $\left(72 / 275^{\circ}\right)$ founded on the Myrtle of S. Europe, and extended along sinilar lines to a great tree-group with opposite gland-dotted leaves, a flower with indefinite stanens in tassel-formation, offering abundant pollen, no nectary, a syncarpous ovary with axile-placentation, and a single style. The floral organization is thus fundamentally Cistifloral (cf. Guttiferac), but the gynoecium shows further advance in the complete 'fusion' of the style (with no trace of vestigial carpels), and the pocket-formation of the inferior ovary. Individual genera may present further elaborations of the type:-

Eugenia caryophyllata, Clove (Jambosa Caryophyllhs), cult. in Tropics; evergreen with decussate leaves and axillary clusters of few flowers; tetramerous, receptacletube and sepals crimson, unopened bucis ( 12 mm.) collected for eugenol; petals pink, shed as a cap on opening $(5 \mathrm{~mm}$.) ; stamens inarched in bud, divergent in flower as tassel-cluster, $8 \mathrm{~mm}$. orer all; single stout style, $3 \mathrm{~mm}$., ovary with many ovules : fruit of enlarged receptacle, indehiscent, with 4 apical calyx-teeth : cf. Eugenia-forms with free petals $(625)$, Jambosa, petals shed as cap (1 20), Sy'zygium, corolla a fused cap ( 140$)$.

Engenia Jambos, Rose-Apple, a small tree, cult.: the more generalized type; flowers large, greenish-white, $2-3$ in. diam.; 5 petals fiee, stamens indef. tassel, to mm.; carpels 2, style $40 \mathrm{~mm}$. : Fruit a berry-form, $\mathrm{I}-2 \mathrm{in}$. diam., pink, edible.

Eugenia Jambolana (= Sy'zygium), a large evergreen tree, cult. and widely distributed: Petals fused as a 'calyptra' thrown off on expansion in one piece, stamens as a white cluster: Fruit a purple-black drupe, juicy and edible, $\frac{1}{2}-1 \frac{1}{2} \mathrm{in}$. long, with I or more seeds; taken by birds and flying foxes.

Eucalyptus, a great Australian genus ( 160 ) of tall evergreen trees, growth rapid, many introduced, of. :-

E. globulus, Blue Gum of SE. Australia, cult. in Nilgiris, a tall tree with dimorphic foliage (juvenile leaves only decussate and waxy blue); flowers large, showy; I-2 in. leaf-axils; sepals obscure, petals fused in massive calyptra, stamens indef. in tassel-formation, spreading; ovary $3^{-6}$ locular, many orules; style simple : fruit hard and sclerosed, dehiscing apically; seeds numerous, small.

E. amy'gdalina, Red Gum, the tallest Dicot. $300 \mathrm{ft}$, similar in flower and fruit.

PsidiumGuayava, S. American tree, Guava, cult. ; flowers white, $1 \frac{1}{2} \mathrm{in}$. dian. ; fruit enlarged inferior ovary, as succulent edible berry-type, 2 in.

Lecythidaceae (I8/1 30), based on S. American Lecythis, and separated by leaves spirally arranged, not gland-dotted, otherwise highly specialized lines of tropical forest-trees; organization essentially: Cistifloral, with characteristic specialization in androecium: cf. Lecjthis, Monkey Pot; Couroupita guianensis, small trees, flower massive, $5^{-6}$ merous, $3^{-4}$ in. dian.; the receptacle is extended unilaterally to 
a broad thong with stamens, reflected over the primary androecium, hence sternotribal and nototribal: carpels 6 , fruit a capsule, large and woody, dehiscing by a lid.

Berthollotia excelsa, J3razil Nut, tall tree of S. Amer. forest; calyx fused and splitting into 2 parts: flower $\mathrm{I}$ in., tetramcrous; androecium with reflected region. Fruit a large wooden capsulc, 4-locular, 2 rows of large seeds in each loc. a small cover cut of as lid with placental region. Seed as a large 'nut'; embryo massive, not differentinted, no endosperm.

Barringtomit, tall trees of strand-forest. B. speciosa of Malay, flowers $5^{-7} \mathrm{in.}$., stamens $3^{-4}$ in. long. Fruit $3^{-4}$ in. diam.

B. racemosa S. India, flowers tetramerous, 2 in.; fruit ovoid $2 \frac{1}{2}$ in.

Carcy arborea, large deciduous tree of savannah-land: flowers tetramerous, 2-3 in. diam.; androecium gamoplyyllous below, with many staminodal filaments: fruit green, sub-globular, berry-type, $2-3$ in. diam.

Lythraceac ( $\left.21^{\prime} 450\right)$, based on herbaceous Lithrum Salicaria of Europe, and extended to tropical trees with similar floral organization; i.e. a receptacular tube which does not affect the ovary (still 'superior') : leaves opposite, 'calyx-tube' takes up sepals and petals (or stamens in part). The intercalated growth is protective and secretory; the flowers are still essentially Cistifloral, of reduced type, with axile placentation, and the fruits are dehiscent many-seeded capsules.

Lages'stroemia parviflora, large timber-tree of deciduous forest, associate of Sal, leaves opposite, simple: inflorescence few-flowered $\left(3^{-6)}\right.$ : flowers white, fragrant, 10-12 mm. dim., 6-merous; stamens $30-40$, 5 antisep. (10 $\mathrm{mm}$.) longer than the others $(5 \mathrm{~mm}$ ) ; good cup-shaped receptacular tube $(5 \mathrm{~mm}$. diam.), stamens from base. Fruit a coriaccous capsule, I in., loculiciclal with 3 stout valves: seeds numerous, winged, $15 \mathrm{~mm}$.

L. indica of China, cult. for large rose-coloured flowers, 2 in. diam., 6 larger stamens, petals crumpled and crisped on margins.

L. Flos Reginae, chief timber-tree of Bengal and Assam, in moist situations; panicles of large purplish flowers 2-3 in. cliam., 6-merous, petals crumpled in bud, stamens $100-150$, all equal.; carpels $6(7-8)$, antisepalous; Receptacle-cup massive, stamens horne $\frac{1}{2}$ way up; Fruit a woody capsule, opening distally, loculiciclally by 6 wide slits. Seeds numerous, angularly winged, Io mm.

Lawsonia alba, Henna, a small hedge-shrub, often spinous; nowers greenishyellow, $\frac{1}{4}$ in., 4 -merous, stamens in 4 anisep. pairs, capsule dehiscing irregularly.

Woodfordia floribunda, common gregarious shrub of dry hill-sides; Flowers clustered, hrieht recl, 6-merous, zygomorphic: stamens 12 from base of receptacle tube.

Sonueratia acida, small tree of tidal crecks and Mangrove formation (Sundribans, \&c.), Leaves oborate, opposite, light glaucous green : slender preumatophores from horizontally spreading roots. Flowers perigynous, 6 -merous, 2 in. diam., petals purple; fruits edible, 2 in. diam.

$\mathrm{S}$. apetala, similarly common in Nangrove-formation, gregarious, to $5^{\circ} \mathrm{ft}$., fowers tetramerous, apetalous, $r$ in. diam.; fruit a capsule, $\frac{3}{4} \mathrm{in}$.

Rhizophoraceae (15/60). Based on the Mangrove (R. Mangle) of Trop. Amer., characteristic of halophytic swamps and muddy sea-margins (Mangrore-belt). Flowers cucyclic, Discifloral, in few-flowered cymes, 4-merous, I in. diam. Stamens $4+4$; ovary of 2 median carpels, each 2 ovules. Fruit 1 -seeded, the seed germinating in sill, to a long (ro in.) pendulous embryo (mainly hypocolyl-axis), detached into mud ('viviparous').

R. mueronata, Tropics of Old World, similar, on sea-face of Mangrove-belt, with stslt-roots submerged at high-tide. Flower $\mathbf{I}$ in. diam., stamens 8 ; Fruit 2 in., and embryo with hypocotyl extending to $2 \mathrm{ft}$. or more.

Bruguiera gymnorhiza, a large tree behind the Rhizophora, no stilt-roots, but respiratory 'knees'; also viviparous, hypocotyl $\mathrm{I}-2 \mathrm{ft}$.

Carallia integerrima, large tree of inland forest ; leaves coriaceous, glossy ; Flowers in similar clusters of the same type, eucyclic, 6-8 merous, 4 carpels; fruit small, I-seeded. 
Combretaceae $(1 ; / 450)$ of essentially tropical trees, with very characteristic advanced floral organization, eucyclic and Discifloral; petals may be wanting, but the inferior ovary is unilocular with 2 (or more) pendulous ovules, and single style-shaft. The fruils are I-seeded nuts, indehiscent, and commonly angular or winged.

Torminalia Chebula, a large tree of mixed deciduous forest; Flowers small, greenish, in short panicles or spikes, ape'alous, ny-pollinated, odour disagreeable, many staminate only. Fruit obovoid, or 5 -angled, $1 \frac{1}{2}$ in. (Myrobalans), 1 -seeded, without endosperm, cotyledons large and convolute (in transv. sect.), storing fat.

As important representative species, cf.:-

T. Catappa, Beach-forests of the Andamans, planted and cult. for edible sceds (Indian Almond); halophytic, fruit floating, 2 in., 2 -angled, 2 -winged with fibrous pericarp and strong sclerocarp.

T. belerica, large deciduous tree, $120 \mathrm{ft}$., common except in driest regions: fruit oroid, I in., with harrl sclerocarp, taken by animals.

T. tomentosa, a large deciduous tree, $100 \mathrm{ft}$. common, except in desert tracts, young branclies and leaves with rusty pubescence. Fruit 2 in., with 5 broad longitudinal coriaceous wing-ridges, and hard bony sclerocarp.

T. Arjuna, a large buttressed tree, nearly evergreen, common on banks of streams, leaves coriaceous; fruit similar, more spindle-shaped, wings narrow.

Anogeissus latifolia, a large tree characteristic of dry deciduous forest, leaves turn copper-red in cold season. Flowers in small globose capitula ( $\frac{1}{4}$ in.), minute, apetalous, receptacle-tube elongated. Fruit very small, a samara, 2 -winged, $5 \mathrm{~mm}$., with remains of receptacle-tube as beak ( $4 \mathrm{~mm}$.).

As types of particularly isolated series, cf. :-

Hamamelidaceae (is/50) based on Hamamelis, Wych-Hazel of N. Amer., commonly placed near Saxifrages from the receptacle-tube being partially free and the gynoecium of 2 carpels, 2 -loc., 2 styles, and fruit a capsule.

Parrotia Jacquemontiana, gregarious small Hazel-like tree of NW. Himalya, for wicker and bridge-rope: flowers diclinous, greenish-yellow, in clustered heads, apetalous, stamens 15 ; capsule $\frac{1}{2}$ in., with stellate tomentum, 2 -seeded, with horny dehiscent sclerocarp.

Bucklandia popuinea, a tall evergreen tree of E. Himalya (Darjecling, hillforest); stifules large, enveloping the buds; flowers in clustered heads of $8-20$, fused up; petals rudimentary or wanting; stamens 10-I 4, ovary with several ovules, seeds winged.

Carica Papaya (I'apaw) of Caricaceae (2/30), of Tropical Amer., cult., a small soft-wooded tree with latex, single stem, leaves palmately lobed, to $2 \mathrm{ft}$. across, on long petioles held horizontally; stems with yellow bark and seal-scars; staminate inflorescence pendulous, staminate flower with white trumpet-reccptacle and $5+5$, stamens near top: carpellary flower with free white petals, conspicuous ovary, 5 carpels and 5 elaborate stigmatic branches, parietal placentation. Fruit succulent, with black seeds in sweet pulp. Endosperm stores fat. (Formerly classed with Passion-flowers, from fruit.)

Tetrameles nudiflora (Datiscaceae, 4/4), a tall deciduous tree of hill-forest, stem buttressed; flowers on bare stems in branched panicles, dioecious, tetramerous, j mm.; Staminate flower with 4 stamens, carpellary flower with 4 styles, and indefinite ovules on 4 parietal placentas. Capsules shed minute seeds.

Opuntia Dillenii, Prickly Pear of S. Amer. (Cactaceae, 20/1500). Branches: as succulent-flattened cladodes in oborate segments, with leaf-points indicated by sharp spines ( $\mathrm{I}$ in.). Flowers of spirally arranged indefinite perianth above the inferior ovary, yellow; stamens indefinite, shorter than the 'petals'. Ovary' with parietal placentation, many orules. Fiuit succulent, bird-dispersed, pear-shaped, with spines distally.

Araliaceae (51/660), type Hedera, includes Aralia, Gamblea, Dendropanax, following the general lines, with tendency to simple umbellate inflorescence-schemes in panicles. 
BICARPELLATAE of Gen. Plant. (is 876 ), a convenient assemblage of meiocyclic Gumopetalae (the main series), with 'superior' ovary' and of 'hypogynous' construction of the type :- $\mathrm{sep}$. 5, pet. 5, stamens 5 , gynoecium of 2 median carpels, sincarpous. 'The flowers present a great range of floral mechanism and fruitclaboration, and the section is largely separated into families and groups by conspicuour features of somatic organization (c.g. opposite leaves), and the construction of the gynoecium in terms of placentation, as also leading to different types of fruit-formation: the last may range from dehiscent 'follicles' to capsules and indehiscent achenes, schizocarps and cocci, berries and drupes. Families with opposite leaves and actinomorphic flowers may be taken first, as most readily identified by such obvious features : cf. :-

Oleaceao (20/390), founded on Olea (Olive) of S. Europe, extended to Fraximus, Syringa, Ligustrum, Usmanthus, Jasminum (Hort.), distinguished by nowers ranging to tetramery, and in the limit apetaly (Ash), but the androecium remains constant at 2 stamens alternating with 2 carpels of the gynoecium, syncarpous with 2 ovules per loc. Fruit a capsule (Siringa) or berry (Ligustrum), I-seeded samara (Fraximus); including representative species as small trees and shrubs of hill-districts.

Salvadora persica, Mustard-tree, of Salvadoraceae (3/9), a small tree, $30 \mathrm{ft}$., of dry regions, cult., and as halophyte; evergreen with coriaceous leaves. Flowers greenish-white in lax panicles, tetramerous, stamens 4, ovary unilocular with I basal orulc. Fruit a red lrupe, $\mathbf{x}$-sceded, with thin sclerocarp and pungent taste. Otherwise put witl Disciflorae.

Apocynaceae ( $130 / 1000)$, a large family based on Apocy'num of Medit. region, and extended to a wicle range of tree-forms with usually opposite leaves, milky juice (latex) and flowers with convolute corolla and tube-mechanism, commonly mothpollinated: the gynoecium of 2 carpels is fused distally in a common style-extension; these break away' in fruit to give dehiscent 'follicle'-like pods (much in the manner of Sterculia). Seeds commonly packed in the pods with silky hairs subsequently utilized for wind-dispersal.

Alstonia scholaris, large evergreen tree of damp forest, leaves coriaceous, fowers greenish-white, in compact long-stalked cymose clusters. Corolla-tube $8 \mathrm{~mm}$.; fruits slender podk, pendulous, $\mathrm{I}-2 \mathrm{ft}$. ; seeds with fringe of hairs.

Holarrhena antidysenterica, a small tree, common in decilluous forest, often gregariou; ; fowers white, fragrant, $\mathrm{I}-\mathbf{1} \frac{1}{2} \mathrm{in}$. dian. ; fruits slender pods, $8-14 \mathrm{in.}$ $5 \mathrm{~mm}$. diam., seeds with tuft of hairs $(2 \mathrm{in}$.) at one end.

Piumeria acutifolia of W. Indies, cult., very milky, leaves spirally arranged. Flowers on bare stems, fragrant, large, white with narrow tube, and typical mothlype of mechanism; anthers at base of tube, $20 \mathrm{~mm}$. from orifice.

Wrightia tomentosa, a small deciduous tree, flowers brownish, $\mathrm{I} \frac{1}{2} \mathrm{in.}$ diam., with red corona-growths. Fruit a rough pod, $6-12$ in. long; seeds linear, $\frac{1}{2}$ in., with fine silky coma packing the interior.

Asclefindacene $(2 \mathrm{I} 7 / \mathrm{I} 700)$, similarly with opposite leaves, latex, meiocyclic flowers, and 2 carpel-pods divergent in fruit, pass on to elaborated mechanism with coherent pollinia, retinaculum ('spoon' or 'clip') as stigmatic parts taking out jollen from loculi of adjacent anthers. Fly- or moth-pollinated, of highest floral organization in Dicots. ; cf. Periploca (Hort.) spoon-type, nectary on petals; Asclepias (Hort.) clip-retinaculum type ; Ceropegia (Hort.) as 'fly-bottle' trap-type. No timbertrees, but many shrubs and lianoid (Perifloca), also herbaceous succulent (Stapelia).

Loganiaceae $\left(32 / 55^{\circ}\right)$ based on Loyania of Australia, covers the case of opposite leaves, actinomorphic, meiocyclic flowers, no latex, and fruits as many-seeded capsules, as a more generalized group with great range, hence liable to take in forms unt inchuled in the more specialized families. Cf. Buddleia globosa of S. Amer. (Hort.), simple flowers in orange balls, $20 \mathrm{~mm}$. diam.; $B$. z'ariabilis, violet spicate 
panicles, flowers actinomorphic, 4 -merous, $8 \mathrm{~mm}$. diam.; Fruit a small capsule, $8 \mathrm{~mm}$. (Hort.), bee and butterfly-pollinated; seeds small with wing-extension.

Strychnos Nux-vomica, common evergreen trce of S. India, \&c., leaves glossy, flowers greenish-white, in cymose clusters: corolla tubular, $8 \mathrm{~mm}$.; fruit a large orange berry ( $1-2$ in. diam.) with $8-9$ massive seeds (like grey buttons), $15 \mathrm{~mm}$. diam., with solid endosperm.

Fagraea obovata, a small tree, often cpiphytic (as on Teak), with clasping roots : Flowers large, fragrant, with tube $1-1 \frac{1}{2}$ in. long. Berry glossy-green to black, $I-1 \frac{1}{2}$ in.

Boraginaceao $(85 / 1550)$, a largc order, mainly herbaceous, leaves sfirally arranged, fowers typically pentamerous and actinomorphic; gynaecium of 2 carpels, each 2 orules; style gynobasic and fruit separating as 4 dry mericarps (cocci); cf. Anchusa, Symphytum, Myosotis (Hort.); a wider range in :-

Cordia Myxa, deciduous tree of shady ravines in Sub-Himalya, \&c., largely cult.; Flowers, small, white, yo mm., in clustered cymes; styles 2, each 2-fid, not gynobasic; Fruit a drupe, $\frac{1}{2}-1$ in., glossy-yellow, subglobose, turning black, with rugose 'stone' in sweet viscid translucent pulp; taken by birds and monkey's: Seeds I or more, sclerocarp splitting off 'valves' on germination.

Ehretia laevis, common in deciduous forest; flowers in unilateral cymes, white, $5 \mathrm{~mm}$.; style 2 -fid, not gynobasic; Fruit a small orange-red drupe, $5 \mathrm{~mm}$. with 3-4 pyrenae.

Bignoniaceae (100/500) essentially tropical tree and liana-forms, leaves commonly opposite, fowers handsome, more or less zygomorphic, stamens reduced to $f(2)$ in correlation; gynoecium of 2 median carpels, the ovary 2 -locular with a large number of ovules on compound placentas, appearing (in transv. sect.) as 2-lobed in each loculus. Fruit typically a dehiscent capsule with characteristic winged seeds; (wo vilies separate from the median placental tracts (dissepiment).

Stereospermum chelonoides, a large tree of moister deciduous forest; Flowers fragrant, yellow marked with red, $\frac{3}{4}$ in. long. Capsule a slender pod, $10-30$ in., and $\frac{1}{2}$ in. diam., seeds wedge-shaped, sunk in 'notches' of a corky cylin(Jrical dissepiment (like a jointed snake), with wings at each end ( 1 in. over all) shaped to the curve of the dissepiment.

S. suaveolens, in drier districts and with Sal. Fruit $\mathbf{I}-2 \mathrm{ft}$., $\frac{3}{4}$ in. diam., dark grey and speckled; ralves hard and thick, seeds flat and winged.

S. xylocarpum, deciduous tree of Central Provinces; capsule to $3 \mathrm{ft}$, over I in. diam.; woody and tubercled, seeds I in., winged $\frac{1}{4}$ in. at each end.

Cf. also:-Dolichandrone falcata, with white, nearly regular, trumpet-shaped flowers, I-I $\frac{1}{2}$ in. tube; Spathodea campanulata, IV. African Tulip-Tree, with conspicuous zygomorphic red-and-yellow flowers; Millingtonia hortensis, Burma, cult., a large tree with fragrant white flowers; corolla-tube $3^{-4}$ in., slender; 4 stamens at base of tube; fruit capsule 12 in., seeds with 3 transparent wing-ridges. Oroxylum indicum, a small deciduous tree, leaves bipinnate, 3-5 ft.; flowers purplish, corolla $2-3$ in., trumpet-shaped : capsule flat, $\mathrm{I}-3 \mathrm{ft}$. and 3 in. broad, flattened in the plane of the dissepiment; seeds with a papery netted wing, 3 in. broad, flat with a flat green central embryo.

Acanthaceae (173/2050) based on Acanthus of S. Europe, with markedly zygomorphic flowers, 4 stamens, and deliscent fruits; seeds on a special type of placenta. Mainly shrub and herbaceous types, extended to a large no. of tropical slırubs and herbaceous plants, the most important:-

Strobilanthes in many species ( 180 , Indian 21 ), as gregarious shrubs of underwood, or on open hill-sides as dense scrub: more or less monocarpic and flowering periodically, colouring the landscape violet-blue; dying down after fruiting and allowing regeneration of forest-trees. S. auriculatus, $4-6$ ft., with Sal, flowering every 6 years: stem quadrangular, flowers blue, in bracteate spikes $3-5$ in. long; others in hill-country, with representative species.

Verbonaceae $\left(6_{7} / 760\right)$ founded on European Verbena, and cxtcnded to a wide 
range of forms with similar floral construction; leaves opposite, flowers pentamerous, more or less zygomorplic, stamens 4 , carpels 2 median; the ovary generally with 2 orules per loculus, and separating + cocci, dry or succulert ; without the gynobasic style of the Libiatae.

Cf. a wider range in :--

Vitox Negundo, a deciduous shrub of drier regions and waste places, planted in hedges. Sc. Flowers small, violet, in elongated terminal panicles of opposite crmes; corolla $\frac{1}{4}$ in. diam., 2 -lipped ; Fruit a drupe, sclerocarp $1-4$ seeded.

$I^{\prime}$ altissima, a large evergreen tree of $\mathbb{W}$. Ghats: Flowers white, drupe $\frac{1}{4}$ in., also $I:$ fubescens and $V$. linco.r. $\%$, deciduous, of $S$. India, with axillary cymes only, and small drupes similarly f-locular : cl. Clerodendron, Aloysia (Hort.).

Toctona grandis, Teak, a large tree in mixed deciduous forest of both Peninsulas, I 50-1 $90 \mathrm{ft}$. with $100 \mathrm{ft}$. bole, and $7-\mathrm{S} f \mathrm{ft}$ diam.; Leares opposite, lamina $\mathrm{I}-2 \mathrm{ft}$., with grey stellate tomentum, on quadrangular shoots: Inflorescence as terminal erect panicles $(1-3 \mathrm{ft}$.$) , conspicuous in the rainy season, of small white flowers,$ actinomorphic, 5-6 merous, with 5-6 stamens, fly-pollinated. Fruit a hard nut, indehiscent, with corky apex and felt of hairs, further enclosed in the dry saccate persistent calyx ( $1-1 \frac{1}{2}$ in. diam.), + seeds included: dispersed by water-flotation; in germination the sclerocarp splits off I or more 'valve'-pieces laterally, I-4 seedlings from a nut.

Gmelina artorea, a large deciduous tree (roo ft.) of Sub-Himalya, \&c.; Flowers yellowish-brown, pentamerous, all parts softly hairy; corolla $\mathrm{I}-\mathrm{I} \frac{1}{2}$ in., zygomorphic. Fruit a yellow drupe, I in., taken by cattle; sclerocarp dehiscing by valves.

Avicennia officinalis, a large evergreen tree, halophytic in IIangrove Zone (Sundribans, \&c.), common and often gregarious, with respiratory roots. Leaves with slvery tomentum ; flowers small, ro mm., yellow, zygomorphic, stamens 4 ; ovary f-locular, + orules suspended from central placenta. Capsule dehiscing by 2 woody valves, I-seeded only, and the seed often more or less viviparous; seeds floating and germinating, young plants fixed in mud by stiff recurved hairs on the hypocotyl.

Lantana aculeata, a Terbena-like spinous shrub of S. Amer. (Hort.) introduced and a pest in S. Ind. and Ceylon. Flowers, 5 mm. pink to orange-yellow; fruit a small black drupe, $6 \mathrm{~mm}$., taken by birds. 
EUCYCLIC GAMOPETALAE (Heteromerae of Gin. Planl, $18 ; 6$ ), conventionally including at least 3 distincl groups of divergent series of gamopetalous construction with very characteristic features, classified as Eiricales, Primulales, Ebenales (Gen. Plant.).

I. Ericales include Ericaceae $(67,1350)$ with Rhododendreae and allied sections in which the full cucyclic formula normally obtains, together with full number of antipetalous carpels: minor irregularities are to be allowed for; e.g. Erica may be tetramerous, Callunu is only slightly gamopetalous, Vaccinum lias an inferior ovary. Porous dehiscence of the anthers and the general occurrence of 'trigger-mechanism' has continued the older term of Bicornes (Eichler, I 875). Arbutus Unedo affords a typical arboreal cxample of Lirica-organization, with white bell-shaped flower, $10 \mathrm{~mm}$., and succulent red berry-fruit, $\frac{3}{4}$ in. diam.; cf. :-

Rhododendron arboreum, a small evergreen trec of IV. Himalya, at 5,0008,000 ft., semi-gregarious with Quercus incana; garden forms and hybrids of similar organization. Flowers deep crimson, shortly stalked in sub-globular umbel-like corymbs ; calyx rudimentary, corolla zygomorphic, with broad tube, horizontally projected; odd petal posterior, spotted and grooved to nectary-lobes of disc; anthers dehisce by pores, in sternotribal series $(5+5)$, pollen in tetrads, cohering in silky threads; pollination by moths, \&c.: gynoecium syncarpous, with axile placentation, many orules (varying to 6-10-mery). Fruit an erected capsule, I in., dehiscing by valves divergent from central placental shaft; seeds minute, I mm., winged.

R. campanulatum, evergreen shrub, densely gregarious at the upper limit of trees $\left(9,000-\mathrm{r}_{4}, 000 \mathrm{ft}.\right)$ : flowers purple in lax corymbs, long-stalked, similar in organization.

II. Primulales, grouped around the European Primula, have been extended to types in which the ovary presents similar construction with 'free central ' placentation, based on 5 earpels, with 5 antipet. stamens (Primulaceae, 28/500): The Plumbaginaceae $(10 / 260)$ include forms reducing to one ovule only in the ovary; cf. Plumbago (Hort.), Armeria; while the Myrsinaceae (23/1000) normally retain ro functional stamens, or 5 fertile and 5 staminodal. The ovary indicates 5 carpels with rnany ovules.

Aegiceras majus (Myrisinaceae), a small evergreen tree, $20 \mathrm{ft}$., gregarious in Mangrove-forest, presents the viviparous habit. Flowers small, white, $10 \mathrm{~mm}$., actinomorphic, with convolute corolla, 5 stamens antipet., the anther loculi transversely I 2-15 septate. Fruits $\mathbf{I - 2}$ in. long, curved like horns, I-seeded, the embryro commonly germinating on the tree.

III. Ebenales include more generalized residual groups, again falling into 3 divergent series as Ebenaceae $(5-320)$, timber-trees with flowers much reduced and commonly diclinous and apetalous; Sapotaceae (3 $\mathrm{I} / 600)$ trees with latex; and Styracaceae $(6 / \mathbf{r} \mathbf{r} 0)$ trees with resin; hence many economically important.

Diospyros Ebenum (Ebenaceae), Ebony Tree of S. India, a large tree of dry regions, commoner in Ceylon, duramen uniformly and intensely black and hard. Flower; dioecious, tetramerous; staminate small and clustered, with 4 -toothed calyx and 8 stamens with unequally paired anthers; earpellary flowers solitary in leaf-axils, carpels 4. Fruit a sub-globular berry, $\frac{1}{2}$ in. diam., in persistent woody eup of calyx, $5^{-8}$ seeded, with sweet pulp.

$D$. melanoxylon, common in deciduous forest, $50 \mathrm{ft}$., similar to $D$. Iomenlosa (with broader leares) Ebony Trees of N. India, duramen less uniformly black, more or less gregarious in dry forest. Fruit $\mathbf{I}$ in. diam., yellow, seeds $3^{-8}$ in sweet pulp, taken by birds, bats, \&c. Stamens simple and endosperm ruminated. D. Kurzii, Zebra-wood of moist forests of Andamans, large evergreen tree; flowers diclinous, tetramerous, corolla $4 \mathrm{~mm}$., velvety externally, fruits $\frac{1}{2} \mathrm{in}$. diam.

Sapotacea include remarkable tree-types with characteristic floral organization, essentially eucyclic, but ranging to 4-6-8-mery, or with effect of multiple corollas by 
secondary appendages to petals; apparently in some cases the androecium is in more than two wholls, or the inner series is staminodal. Fruils as berry-forms with 1 or several seeds. The family is essentially tropical, and was based on Sapola of Trop. Aner. the fruit of Achross Sapota, Sapodilla.

Palaquium Gutta, Gutta Percha, a large tree of evergreen forest, Malay: lenves and shoots witl, rusty tomentum; flowers small, clustered in leaf-axils, 6-merous: stamens 12-18, ovary 6-locular. $P$. nblongifolium; fruits larger, similar, exploi'ed.

P. ellipticum, a tall tree, soo ft., of IW. Ghats $(4,000 \mathrm{ft}$.), Flowers I in., stalked in the manner of Bassia ; stamens $12-18$, Fruits $1 \frac{1}{2}$ in.

Bassia latifolia (= Illife), a large tree of deciduous fores! of C. Ind., cult. (Mohwa); leaves and fowers clustered at ends of branches; flowering on bare stems with the young leaves; fowers on $2 \mathrm{in}$. stalks, with massive fleshy corolla-tube, more or less drooping, with small floral aperture, soon dropped, and taken by animals. Calyx of $4-5$ free segments, petals $8-10$, corolla-tube $8 \mathrm{~mm}$. by 10 , and $2 \mathrm{~mm}$. thick, witl small free lobes. Androecium of $16-20(30)$ stamens in $2(3)$ altemating series, enclosed in corolla-tube. Gynoecium of 8 carpels, 8-loculi, each I orule: Style $30 \mathrm{~mm}$. projecting from corolla-tube; honey-secretion copious. Iruit a greenishjellow berry; $1-2$ in. with $1-4$ sceds. Cf: -

$B$. longifolia, representative species of S. India, essentially similar.

B. Parkii (= Bulyrospermum) of W. Africa gives 'butter' from cotyledons of large seeds; 8 -merous, with 8 functional stamens, and inner series of 8 petaloid staminodes. Fruit with $\mathrm{t}$ large seed. Cf. B. butyracea of E. Sub-Himalya.

Mimusops Elengi, a large cvergreen tree of dry forest of S. India, much cult. ; Flowers white, fragrant, 1 in. diam.; calyx $4+4$, corolla of 8 petals, each with 2 petaloid appendages, the former convergent on stamens, the latter divergent ; stamens 8 antipet., and 8 alternating staminodes: style simple, ovary with 8 antipet. loculi, each I ovule. Fruit $1 \mathrm{in}$., pale yellow, I-seeded. (The corolla with androecium shed in one piece, with 'daisy-effect 'in daisy chains.)

M. hexandra, a small evergreen tree of C. and S. India (roo ft. in Ceylon), much cult., Flowers 6 -merous, $\frac{1}{4}$ in. diam., petals yellow, with bilobed white accessory segments; stamens 6 , and 6 staminodal processes. Fruit $\frac{1}{2}$ in., yellow.

11. lithralis, a large evergreen tree of sand-hill coast-forest of Andamans, flowers 6-merous, fruits $1 \frac{1}{2}$ in., with several seeds.

M. glnbesa of Trop. S. Amer., Balata, flowers 6-merous of similar construction, I $3 \mathrm{~mm}$. diam., daisy-like on long-stalks, petals with paired accessory lobes. Stamens 6 antipet. with 6 staminodes.

INFERAE (Gen. Planl., I 876 ) comprising the most highly organized of the gamopetalous phyla, presenting the additional specialization of an 'inferior' ovary (epigyny), as also the limiting condition of meiocycly (= Tetracyclicae) of the type $5 \mathrm{~S}+5 \mathrm{P}+5 \mathrm{~A}+2 \mathrm{G}$.

Rubiaceae $(3+6 / 4500)$, a remarkable group, founded on the European Rubia (Madder). and extended to a wide range of tropical trees with opposite leaves and reneralized actinomorphic flowers on these lines. Leaves 'opposite and stipulate' have been regarded as more essential than reduction of orary-contents or axile placentation.

Cinchona officinalis, evergreen tree of mountain-forest of Andes, cult. in vars. (Nilgiris); nowers small in red clustered cymes, 5 -merous; corolla tubular, 15 mn., silky, valsate in bud; style slender, with 2 short stigmatic lobes. Fruit deliscing by 2 valves, along septa : sceds many, small and flat, with membranous wing on margin.

Hymenodictyon excelsum, a large tree of deciduous forest, leaves sinple, petiolate; Flowers white, fragrant, in dense cylindrical panicled systems ; corolla-tube 
slender; style long, exserted; moth-type of pollination. Citpsule $\frac{3}{4} \mathrm{in.}, 2$-valved, dehiscing loculicidally; seeds small, winged marginally:

The Naucleae comprise a special section with globose aggregrated inflorescences as capitula of closely-packed flowers:-

Anthocephalus Cadamba, a large deciduous tree with soft wood, of outer hills and evergreen forest, planted and cult., leaves coriaceous, nower-heads large, terminal solitary, $1 \frac{1}{2}-2$ in. diam., as yellow balls in the manner of Plalanus. Inflorescencereceptacle enlarged in fruit to orange fleshy pseuclocarp (taken by animals and birds), with closely packed capsules; sceds not winged.

Adina cordifolia, a tall tree, common in deciduous forests, leaves cordate and acuminate (Poplar-like); flower-heads I in. diam., yellow, corolla 5 -merous, hairy.

Stephegyne parvifolia, common deciduous tree of outer Himalya, often gregarious : Flower-heads 1 in. dianı, fragrant, greenish-yellow. Flowers pentamerous, corolla-tube $7-8 \mathrm{~mm}$., style long, projecting, $12 \mathrm{~mm}$; stigma club-shaped; nectary as conspicuous disc-collar. Fruit-heads globose, $\frac{1}{2}$ in., with numerous small 2 -valved capsules; seeds $2 \mathrm{~mm}$., pointed and winged at both ends.

Gardenia latifolia, a small tree, floral mechanisn on large scale, distinct mothtype of pollination : corolla pale-ycllow, fading orange ; petals $5^{-9}$, tube $2-3$ in. long. Fruit 2 in., drupaceous, indehiscent, with thin hard sclerocarp. Seeds numerous on $4-5$ parietal placentas.

Coffea arabica (Coffee), a small tree, ${ }_{5} \mathrm{ft}$., of Trop. L. Africa, cult. ; Flowers in axillary clusters, corolla greenish-white, ranging 4-9-merous, tube 6-8 mm., styles and anthers projecting. Fruit a crimson drupe, $\frac{1}{2}$ in. diam., with 2 pyrenae; sclerocarp cartilaginous only; seed ro mm., with solid horny endosperm.

C. liberica of W. Africa, larger leaves, flowers 6-9-merous; fruit I in. diam., crimson, seeds similar; disease-resisting.

Compositae $(806,13,100)$ a huge series of predominantly herbaceous types in temperate regions or on mountain ranges; without definite timber-trees and of minor importance in forestry. For shrubby forms (Hort.) cf. Olcuria Haastii of New Zealand. Flowers white in corymbose panicles of few-flowered $(7-12)$ capitula, with 3-5 ray-florets (July).

Vernonia arborea, a small tree, $60 \mathrm{ft}$., of Hill forest of S. India; Flowers in capitula $(1-6)$, all tubular : pappus of white hairs, $6 \mathrm{~mm}$.

Leucomeris spectabilis, a small deciduous tree of NW. Himalya, bark white, leaves coriaceous, felted white underneath; capitula $4^{-8}$ flowered, in terminal corymbose panicle, 6 in. diam.

Blumea balsamifera, a large aromatic slırub, gregarious, with silky tomentum, in the manner of Artemisia. Capitula of yellow flowers, $\frac{1}{4}$ in., clustered in a leafy panicled system ; pappus red : yields camphor.

Senecio a characteristic genus ( $1,200 \mathrm{sp}$.) of great range; involucre of a single contact-cycle, ray-florets normally present, pappus simple; represented by woody climbers in Hill-forest. 
Is APETALAE may be conveniently grouped families in which there is some suggestive evidence that the petaloid condition luas been lost, and that they may be more or less related to existing polypetalous forms. In absence of very decisive evidence, these may include:-Lauraceae, referred to the Polycarpicae near Berberidaceae, Myristicaceae near Anonaceae: the great series of the Euphorbiaceae as a branch of the liucyclic Discifloral section (Geraniales), with the Buxaceae (Sapindales): the Platanaceae as petaloid and apocarpous suggestre of the Saxifrage-alliance: the Thymeleaceac as reluced Discifloral types, and the Chenopodiaceae generally referred to the Centrosperm series with Caryophyllaccae.

Lauraceae ( $40 / 1000$ ) founded on Laurus nobitis, Bay, of Medit. region; evergreen, flowers in clecussate clusters, dioecious, dimerous, apetalous; Staminate flower of $2+2$ perianth, and 10 stamens $(4+2+2+2)$ with paired glandular appendages on the + inner, and valvate dehiscence of 2 anther-loculi: Carpellary flower of $2+2$ perianth, 4 staminodes (diagonal), and gynoecium of I carpel with I suspended ovule. Fruit a black berry; $\frac{3}{4}$ in., aromatic, with I secd without endosperm. The family is extended to a wide range of tropical forest-trees, in which the full type of flower is hermaphrodite and trimerous, characterized by the peculiar valvate anthers and the limiting term of the gynoecium.

Cinnamomum zeylanicum, Cinnamon, a large tree of S. India and Ceylon, cult. and coppiced; leaves coriaceous, aromatic ; flowers in panicled clusters, greyish,

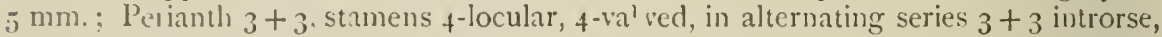
and 3 extrorse, 2 -glanded, followed by 3 staminodes. Style and stigma simple, ovary with one anatropous ovule suspended. The receptacle is crateriform (perigyny), and the construction suggests a relic of a once more complex organization. Fruit a darkf,urple berry, i in. long, taken by birds.

C. Tamala, Cassia-Cinnamon, evergreen tree of E. Sub-Himalya, with glossy aromatic leaves. lilowers yellowish-white, $6 \mathrm{~mm}$. diam. ; Berry black, $\frac{1}{2}$ in., fragrant.

Cf. C. Campliora, a large tree of Japan and forests of Formosa (I0o ft.), cult.; camphor distilled from all parts.

Machilus bombycina, Soom, gregarious in valley-forest of Assam, largely cult. (Muga-silk): flowers of similar type. Perianth $10 \mathrm{~mm}$; berry $\frac{1}{4} \mathrm{in}$.

Litsaea polyantha, a tree of Sub-Himalya, also associated with Soom and cult.; Flowers trimerous but dioccious, in decussate groups of 5 (in the manner of Laums); stamens all introrse and 4 -valved; carpellary flowers of $3+3$ perianth and typical ovary. Fruit on elongated pedicels and appearing clustered.

L. zeylanica (= Titrademit), a small evergreen tree of Hill-forest, S. Ind. and Ceylon: Flowers in compact axillary clusters, perianth 4 -lobed, stamens 6,2 innermost biglandular, all +t-valved.

Beilschmiedia Roxburghiana, evergreen tree of Assam, \&c. ; Flowers hermaphrodite, trimcrous; Perianth $3+3$, 10 mm. long; stamens $3+3$ introrse, 3 extrorsc, and 3 staminodes, the 3 rd whorl biglandular (as in Cimnamon), but the anthers delisce by 2 valves only (as in lamrus). Orary typical, fruit about $\mathrm{I}$ in.

Myristica fragrans, isolated type of Myristicaceae, following similar extreme phases of reluction. Evergrcen tree (30-60 ft.) of E. Indies, and cult. : Staminate flowers in pranicled cymes, perianth trimerous, gamophyllous, and a staminal column with 20 or so fused anthers: carpellary flower of perianth including 1 carpel with I basal anatropous ovule: Fruil a large yellow berry-form, 2 in., with I large seed (Nutmeg) with ruminated endosperm and scarlet fenestrated aril (Nace).

Euphorbiaceae, a scries of Eucyclic Geraniales, in all stages of diclinous specialization: Staminate flowers may be wholly aberrant, and the carpellary flower attains the limit of a Tricoccus-fruit of characteristic construction, syncarpous, superior, of 3 carpels, with 2 (or 1 ) suspended ovules in each loculus, raphe internal, and 3 style-branches (often bifid); Fruit normaily a dry clehiscent, explosive, capsule, 
3-seeded: Endosperm stores oil, and the seeds show a 'caruncle' as a cap over the micropyle.

A vast order $(208 / 4500)$ with many forest-trees, though not of first-class timber production, ranging to desert-succulents (leafless and with spiny stipular thorns) and herbaceous forms of N. Temp. woodland (Mercurialis). The genus Enflortia (600) as the extreme case (with Cyathium) affords little idea of the entire scries. The structure of the gynoecium is most constant : ef. Mlercurialis with 2 carpels; 5 carpels, antipet., in Wielandia of Seychelles; more indefinite in Hura. Thougli predominantly apetalous, many genera retain petals; as a series typically fly-pollinated. As special feature note stipules and their relation to extrafloral nectaries. For more elementary stage of flower, cf. first:-

Jatropha Curcas, herbaceous form of 'Trop. Amer., cult.; Flowers in axillary panicles, small, of Discifloral habit: staminate flower 5 sep., 5 pet., $5+5$ stamens and 5 extrastaminal disc-lobes: carpellary flower 5 sep., 5 pet, disc-lobes and staminode rudiments, ovary with 3 branched stigmatic lobes and 3 loculi each $\mathrm{I}$-seeded: fruit a capsule, $\mathrm{I} \frac{1}{2}$ in.

Manihot Glaziovii, Ceara Rubber, of drier tracts of Brazil, cult. in less humid stations than Hez'et. Leaves palmately cut in $5-7$ deep segments; flowers monoecious in terminal panicles, I in.; staminate flower apetalous, 5 sep. as gamophyllous bell, purplish inside, $5+5$ stamens and 10 yellow disc-lobes; carpellary flower gamosep. of 5 segments. Fruit $\mathbf{I}$ in. diam. with polished mottled seeds.

11. utilissima, Manioc (Tapioca).

Hevea brasiliensis, Pará rubber, a large evergreen tree of Amazon swampforest, leares trifoliate; flowers, small $(5 \mathrm{~mm}$.) in large panicles; staminate flower 5 sep. and $5+5$ stamens as anthers sessile on central 'column'; nectary as ro-lobed disc: carpellary flower of gamosep. caly $\mathrm{x}$ and ovary with bilobed stigmas and 3 ovules. Fruit a large tricoccus-capsule, 2 in., seeds large ( $\mathrm{I}$ in.) mottled as in Ricinus.

Ricinus communis, soft-wooded tree of Trop. Africa, cult. as annual for Castor Oil. Leaves large, palmately lobed; inflorescences axillary, reduced to few-flowered panicles: staminate flower of 5 sep. and a multibranched androecial region ( $15 \mathrm{~mm}$.) with anthers on all end-ramuli (one of the most aberrant staminate constructions): carpellary flower a conspicuous tricoccus-ovary with shaggy or spinous emergences. Capsule explosive, seeds mottled, with distinct caruncle, well-defined embryo, endosperm with oil and aleurone.

Cp. Hura crepitans, Sand-box tree of W. Indies ; carpels $I_{5}-20$, capsule explosive, 3 in. diam.

Bischofia javanica (=trifoliata), deciduous tree of damp forest of SubHimalya. Flowers dioecious, apetalous; staminate flower of 5 sepals and 5 superposed stamens, no disc-lobes, but a rudimentary central column: carpellary flower with ovary 3 -locular and linear styles. Capsule a globose, succulent berry, $\frac{1}{4}$ in. diam., with parchment-lıke sclerocarp.

Bridelia retusa, a large tree of deciduous forest, leaves coriaceows, elliptical; Flowers yellow, clustered on slender spikes; staminate flower with 5 stamens on slight column, and conspicuous disc: carpellary with 2 -locular ovary and bifid styles. Fruit a clrupe, $\frac{1}{3}$ in., sweet, purple-black, edible, and taken by birds.

Mallotus philippinensis, a small evergreen tree of Sub-Himalya, common in Sal forest; Flowers dioecious, $5 \mathrm{~mm}$., in panicled spikes; staminate flower with 20-30 stamens; carpellary with conspicuous papillose sessile stignas. Capsule 3-lobed, covered with glandular hairs secreting a red resin (Kamela-powder giving an orange dye).

Sapium sebiferum, Chinese Tallow tree, cult. in NIV.; flowers in spicate racemes, monoecious, with the carpellary flower at the base of the spike; style with 3 long spreading stigmas; staminate flower of 2 stamens only and perianth rudimentary. Capsule with 3 seeds, a thick layer of fatty material surrounding them.

Putranjiva Roxburghii, evergreen tree of river-banks, cult., leaves coriaceous, 
flowers dioecious. Staminate flower of 3 sep. and 3 stamens; carpellary with 3 cularged papillose stigmas. Fruit a drupe, taken by deer, with one characteristically rugose 'stone' (necklaces), sclerocarp very hard, spliting on germination, I-sceded.

Excoecaria Agallocha, a small evergreen halophytic tree of Sundribans and tidial forest, fo ft.; flowers minute; staminate in yellowish-green catkins with long stamens 3 ; carpellary 3 -merous. Capsule to 1 in. diam., 3 -lobed, and separating into 3 cocci from central axis. Latex blistering.

Cleistanthus collinus, a small tree of S. Inclia, on dry rocky ground, as coppice. Flowers yellowisli-green in small axillay clusters. Capsule $\frac{3}{4}$ in., woody with 3 scecls.

Phyllanthus Emblica, common tree of mixed deciduous forest with light feathery foliage; leaves small and pectinated on D.V. twigs, looking like pinmate leaves when young, and shed as phyllomorplas. Staminate flower 6-parted with 6-lobed disc. Carpellary with 2 ovules in each loculus. Fruit globose, fleshy, $\frac{3}{4} \mathrm{in}$. with 0 -ridged sclerocarp and 6 seeds. Fruts collected as Emblic Myrobalans.

Buxaceae $(6,30)$. based on Buxus of S. Furope, differs in floral organization, also diclinous (monoccious), apetalous; evergreen, with decussate leaves and reduced axillary racemes: staminal flower dimerous with + stamens; carpellary terminal, of 3 carpels with 3 divergent stigma-lobes; 2 orules suspended in each loculus, raphe external. Fruit a dry capsule, discharging 6 seeds; seed with a small caruncle: cf. Burus scmperivens (Hort.) and B. Wallichimu, very similar in Hill-forest, Ilimalya, at $4000 \mathrm{ft}$.

Platanaceae (r/6), based on Plalanus, Plane, now generally accepted as petaloid with minute petals, diclinous with reduced construction.

$P$. oricnlalis, a large deciduous tree, cult., NW. Himalya ; leaves deeply $5-7$ lobed: fruiting capitula spherical, $\mathbf{I} \frac{1}{2} \mathrm{in}$. diam., $5^{-6}$ in one system. Aclienes hairy, I-seeded, wind-dispersed.

Hernandiaceae $(4 / 24)$, a small series of trees with anomalous characters, apetalous, the reduced flowers with irregular number of parts. The anthers dehisce by 2 valves, and the ovary is inferior with I suspended ovule; commonly included near Lauraceae (Engler, I891).

Gyrocarpus americanus, a deciduous soft-wooded tree of sea-coast throughout the tropics: flowers in dense clusters on panicled systems of many staminate and few hermaphrodite: the latter of $f$-parted perianth and sessile stigma. In fruit 2 larger perianth-segments extend as leafy lobes, $2-3 \mathrm{in}$. long, at the end of the ovoid velvety fruit, $\frac{3}{4}$ in., to constitute spinning-mechanism suggestive of a Dipterocarp. 
MONOCHLAMYDEAE include groups in which the floral organization is apparently primitively 'apetalous', in the sense that the essential floral organs are invested by a simple perianth as one contact-cycle of protective leaf-members. In all cases associated features of cxtreme reluction prevail in the general construction (dicliny, dimery, trimery), and may be combined with extreme specialization in the gynoecium (dicliny, dimery, syncarpy, inferior ovary, and reduced output of ovules and seeds). Such phenomena suggest that little reliance can be placed on these features as indicating primitive nature, and many extreme cases remain so isolated that any serial arrangement is wholly arbitrary. The individual families are usually distinguished by some one dominant character, the exact bearing of which may be wholly rague. A rough distinction may always be drawn between types with simple floral receptacle and those in which epigyny has been attained, and special cases of gynoccium-elaboration may be isolated.

Urticales (Eugler, I912, = Urticinae, Eichler, I878), a large section conveniently grouped around the familiar Urtica (Sting Nettle) of the N. Temp., and extended to include a vast series of types characterized by advanced flowers (predominantly diclinous and dioecious, apetalous and dimerous) with the gynoecium as the limit of syncarpy' ( 2 carpels), still 'superior', but containing only I ovule, and setting $\mathrm{r}$-seeded indehiscent fruits.

I. In the Urticaceae $(4 \mathrm{I} / 500)$ the ovule is typically orthotropous with basal placentation, as the most special case; few are shrubby. Tropical herbaceous Nettles sting badly ( $U$. stimulans, $U$. urentissima).

Laportea crenulata, a small tree of Hill-forest, very virulent; leaves elliptic, may be entire ; flowers small ( $3 \mathrm{~mm}$.) in loose axillary panicles, all parts with stinging hairs. Girardinia zeylanica, fibres as textile retain 'stinging' properties.

Boehmeria nivea (Ramie, Rhea) of Malay, cult., monoecious, herbaceous and shrubby, cult. for fibre of annual shoots (6-1o ft.), leaves serrate, with drip-tip; important textile.

II. Ulmaceae $(13 / 132)$, based on Ulmus, Elm, with small clusters of hermaphrodite flowers, produced in spring before the leaves, of pentamerous type (per. 5, stamens 5, carpels 2), with I ovule suspended, micropyle upward; fruit a winged samara, seed without endosperm : cf. :-

Ulmus Wallichiana, a large deciduous tree of NIV. Himalya (at $1-2$ miles elevation) in damp ravines. Flowers in globose clusters, perianth $4 \mathrm{~mm}$.; samara $\frac{3}{4}$ in. diam. with seed centred.

Holoptelea integrifolia, a large deciduous tree of Sub-Himalya and hillregions, with entire leaves: flowers hermaphrodite and staminate only, in loose mixed racemes: samara I in. diam., on an elongated stalk, I in., no distal notch.

Celtis australis, deciduous tree of NW. Himalya and S. Europe, cult.; flowers small, the hermaphrodite solitary or in pairs, axillary: fruit a drupe, $\frac{1}{2} \mathrm{in}$., red or black, sweet.

Trema orientalis, a small short-lived tree. of NW. Himalya, and cult.; coming up in clearings of damp forest: Howers mixed in axillary clusters; Fruit a small black drupe $(4 \mathrm{~mm}$.) with persistent per. segs.

III. Moraceae (55/900), a tree-series, with latex, the flowers small and aggregated into complex conclensed cymose inflorescences which may encl in taking on the mechanism for pollination. Individual florets then reduce to extreme limits, but the superior ovary retains two stigmas and one suspended anatropous ovule; fruits as minute achenes or drupes commonly become united in a succulent aggregated fruit-mass giving pseudocarps of very striking character and of economic value.

Morus alba, White Mulberry; a deciduous tree of W. and Central Asia, commonly cult. N. India, for silk-industry, and with Sissoo: flowers monoecious, 
often on distinct branches; carpellary flowers with 4 per. seg.; in fruit these enlarge and enclose the drupe-fruit, becoming united in a succulent aggiegated edible mass. Cf. M. indica, of E. and S. India, cult. for silkworm, fruits dark-purple.

Broussonetia papyrifera (Hort.) Paper-Mulberry, a small deciduous tree, Burma, dioecious; staminate flowers in pendulous catkins, 4 per. seg., and 4 inflexed stamens: carpellary inflorescence, splecrical, $\frac{1}{2} \mathrm{in.}$, with closely aggregated perianths and elongated filiform pink stigmas. In fruit the inflorescence-receptacle enlarges, and the achenes hang out on fleshy stalks.

Antiaris toxicaria (= Saccidera) Upas Tree, an enormous trec (250 ft.) of evergreen forest, W'. Ghats, \&c., with buttressed stem, soft wood; flwers monoecious, the staminate on a mushroom-shaped receptacle ( $\mathrm{i}$ in. diam.) and sunk in depressions; stamens $3-8$; carpellary flower solitary in leaf-axils, with involucre of bracts and 2 long styles: fruit drupaceous, $\frac{3}{4} \mathrm{in}$.

Artocarpus incisa, Bread-fruit of Pacific Islands, cult, over 'Tropics: leaves large, deeply cut, flowers in massive inflorescences, inuch reduced; staminate system club-shaped, pendulous, with flowers reduced to I stamen in 2-4-lobed perianth: carpellary inflorescences sub-spherical, flowers sunk under convergent perianth-lobes, with ovary well below the surface, the elongated style, filiform, bilobed, and projecting at the surface. Fly-pollinated; in fruit the inflorescence forms a large spheroidal mass with starch-storage and smooth areolate surface, 6-10 in. diam.; seeds immersed.

A. integrifolia, Jack Fruit of W. Ghats, cult.; staminate inflorescence $2-6$ in. long., fruit rough, with conoidal projections of enlarged perianth-segs. ( $\frac{1}{2} \mathrm{in}$.) for each flower, to size of large Marrow ( $30 \mathrm{in.})$ : cf. also:-

$A$. hirsula, timber-tree of evergreen forests of W. Ghats, to $200 \mathrm{ft}$.; staminate inflorescence slender, 3-4 in., ultimately pendulous; carpellary infurescence $\mathrm{I}$ in. diam., in fruit $3^{-4}$ in., densely covered with hispicl spines : seeds $\frac{3}{4} \mathrm{in}$.

A. Chaplasha, a large deciduous tree of Sub-Himalya and S. Hill-forest, the globose pseudocarps, $3-4$ in., edible, with few large seeds $\left(\frac{1}{2}\right.$ in. $)$ taken by birds and monkeys. A. Lakoocha of Hill-forest, cult., fruit globose, irregularly lobed, with orange pulp and seeds $\frac{1}{2}$ in., taken by monkeys and birds.

Ficus (600), the culminating genus of the series; inflorescence with diclinous reduced flowers assuming a chamber-mechanism with narrow ostiole, through which small insects enter for pollination; in this way the inflorescence-cavity becomes a domicile, and the flowers are utilized by 'gall'-insects, eggs being laid in the ovarics of flowers specially' adapted as 'gall'-flowers, the larva replacing the ovule.

In the simplest case (Crostigma-section) staminate flowers, carpellary, and gallflowers are all mixed in the same chamber-systen, which subsequently becomes a pseudocarp enclosing the small drupes of the individual flowers. Production is continuous, or becomes more or less seasonal in dry forest, and the generations of the insect are correlated with the production of flowers; 79 sp. Indian.

Ficus bengalensis, Bor (Banyan), of Sub-Himalya and S. India, greatly planted, to rooft. high, with descending aerial roots as 'props'; epiphytic as a seedling with descending roots to soil, growing freely from cuttings. Given time there seems to be no limit to lateral extension (assisted). Calcutta tree, scedling of $1782,100 \mathrm{yds}$. diam. and $4^{6} 4$ props, 1900. Nerbudda tree, covering nearly i sq. mile. Attaining great age. 2.200 yrs, recorded. Staminate flower of I stamen, carpellary with I stigma-lobe more pronouncel. Fruit small, globose, $\frac{1}{2}-\frac{3}{4}$ in., scarlet when ripe. Host-1rees hecome 'Ficus-bound'.

F. religiosa, Peepul, a large spreading tree of Sub-Himalya, much planted and growing from suckers. Tree of Budh-Gya from 500 в. c. Foliage like Poplar, tremulous, with long drip-tips, I-2 in.; epiphytic or on buildings. Fruits $\frac{1}{2} \mathrm{in}$. diam., dark purple.

F. infectoria, large deciduous tree of N. and Central Inclia, figs small, $\frac{1}{4} \mathrm{in}$.

F. elastica, India Rubber, gigantic evergreen tree, 100-I50 ft. and crown to $200 \mathrm{ft}$. diam. : germination epiphytic, trunk buttressed, roots spreading on soil 
( $150 \mathrm{ft}$. ) and anastomosing, aerial roots descending, leaves coriaceous, I ft. or more long : figs, $\frac{1}{2}$ in., yellow, taken by birds.

$F$. glomerata of Niomorphe-section, with staminate flower of 2 stamens. A common large deciduous tree in ravines and damp places; all types of flower in same receptacle, fruits nearly globose, $\mathbf{1} \frac{1}{2} \mathrm{in}$. diam., clustered on the leafless branches and spurs of older wood. Commonly full of insects; taken by monkeys and deer.

$F$. macrecarpa, a climbing shrub of Hill-forest, with large fruits to $2 \frac{1}{2} \mathrm{in}$. diam., white spotted green, clustered on the old wood.

F. Carica, common Fig (Eusyse-section), more primitive in the individual flowers, but much further advanced in seasonal adaptation (the form farthest north) to a colder extra-tropical climate, with limiting case of insect-association and marked deciduous habit. A large tree of E. Medit, and W. Asia, cult., growing freely from cuttings, and fruiting as a shrub. Staminate flower with perianth of 5 teeth and stamens $5(4-7)$ : carpellary fower with long style, $2 \mathrm{~mm}$., and one stigmatic lobe rudimentary: Gall-flowers have styles of half the length, correlated with that of ovipositor of Blastophaga wasp. Fruits as minute drupes with slsarply angular sclerosed 'stone'.

In Medit. region 3 crops of figs follow the annual succession, and 3 generations of gall-wasps. (I) Spring-crop (Profichi) of basal gall-flowers and staminate flowers produced later near the ostiole, borne on the old wood with the young leaves. (2) Summer crop on new growth, of few gall-flowers and mostly carpellary nowers, giving the edible fruit-crop. (3) Autumn set with gall-flowers and a few carpellary: The 3 crops act practically as staminate, carpellary fruiting, and a perennating stock, respectively. Only cross-fertilized figs of (2) give good commercial 'figs' with fertile seeds. Seedlings come up as 'Wild Figs' with Profichi fruit. Cuttings of Profichibranches remain as staminate 'Caprifigs', used for pollination. Cuttings of fruiting figs (= var. domestica) cult. in this country; without Blastophaga, give inferior but edible pseudocarps without seeds. 
CUPULIFERAE (Gen. Planl., r 880), include families of Monochlamydeous series with reduced flowers (tending to trimery', dimery, dicliny, and anemophily), with inflore:cences more or less of catkin-habit and characteristic protective investments of the developing fruit as 'cupules', \&c. (Fagaceae, Betulaceae). With these may be associated other stray residual series distinguished by different modes of ovaryorganization (supcrior or inferior, with axile, parietal, or basal placentation) Juglandacene, Salicaceae-all with representatives in the British Flora, as also tropical Casuarinaceae. Any evidence of a former petaloid state is wholly wanting.

I. Betulaceae, flowers in catkins, monoecious, dimerous; carpellary flower with ovary of 2 carpels, each loculus 1 ovule: fruit a nut with I secd, retaining traces of endosperm, and storing fat: subtending bracts and prophylls more or less retained as protective investment of fruit; cf. Befula, Almus, Corylus, Carpinus, Ostrya of N. Temp., with representative sp. in Himalya at 2 miles elevation-Belula utilis at the limit of trees; Almus milida, a large tree at lower elevations, and Carpinus viminea near streams.

Corylus Colurna, a moderate-sized deciduous tree of NIV. Himalya, often gregarious; staminate catkins abundant, pendulous, $+\mathrm{in.}$; fruits in large clusters with laciniate cupule-iniolucre, enclosing small nuts with thick shells.

II. Fagaceae: Flowers monoecious, trimerous; carpellary flower with $3(6)$ carpels, axile placentation, 2 ovules per loculus; fruit a nut, I-sceded, without endosperm, cutyledons store starch-cf. Quercus, Fagus, Castanea of N. Temp. flora. Fagus does not occur, and Cuslanea only as introduction. Quercus is at its optimum in Hill-forest, 37 sp.; cf. NIV. Himalyan types :-

Quercus incana, White Oak, Ban, gregarious in NW. Himalya at 4,0008,000 ft. (Simla level), with Rhododendron, Deodar and Pinus. A large evergreen tree, 60-80 ft., dull-green leaves, coriaceous, serrated, and white below, 3-6 in.; Acorns solitary or in pairs, I in. long, ovoid, conical, pointed, in small rough woody cupule, fruiting i; months from flowering, and so borne on previous season's wood.

Q. dilatata, Green Oak, Moru, at elevations of 7,000-9,000 ft. (English level), semi-gregarious, in ravines with Picea Morinda, \&c.; Leaves coriaceous, shining, serrations jagged and pointed, nearly evergreen. Fruits, pointed, I in., nearly sessile, in normal cupule, $\frac{1}{2}$ in. diam.; Fruiting $\mathrm{r}_{5}^{-1} 7$ months after flowering.

Q. semecarpifolia, Brown Oak, Kharshu, more deciduous; older leaves entire, $2-f$ in., coriaceous, brown underneath, gregarious in upper zone of $8,000-$ I 2,000 ft. (Alpine level) with Birch, Ycw, \&c.; staminate catkins in bunches, 2-6 in. long ; fruits solitary, taking 15 months, I in. diam., black, with rounded end, in thin shallow cups with pointed scales. Cf. also of special interest :-

Q. lamellosa, Buk, of E. Himalya (Darjeeling), roo-120 ft.; acorns 2-3 in. diam., almost immersed in woody cupule, with about ro concentric lamellar ringgrowths.

Q. Griffithii of Assam and Burma, a large deciduous and gregarious tree, acorn more cylindrical, on short spikes; also with remarkable scaly galls, to $\mathbf{r} \frac{1}{2}$ in.

Q. spicata, Pasania-type, a large erergreen tree, with shining leaves of Castanec $r$-type ; staminate catkins erect, in long panicled systems, to $8 \mathrm{in}$.; carpellary systems with many triads $(30)$; in fruit to a foot long, with to roo shining acorns, cup $\frac{1}{2}-1$ in. diam. As extreme case cf. :-

Q. magnifica, in evergreen forest of Shan States, woody cupule $\frac{1}{8}$ in. thick, and acorn woody, $\frac{1}{8}$ in. thick wall, and lobed cotyledons.

Castanopsis tribuloides, evergreen tree of E. Himalya and Hill-forest, more or less gregarious; leaves coriaceous, entire; staminate catkins erect, in terminal systems, in the manner of Castanea; carpellary catkin with numerous triads, each with spinous cupule of Caslomed type; in fruit to ro in. long, with many burr-cupules, 
I in. diam., spines long ( $\frac{1}{2}$ in.) and stellately branched; included nuts, 2-3, cotyledons ruminated.

Juglandaceae $(6 / 33)$ representative of a wholly isolated series, based on Juglans regrid, IValnut, indigenous to Ilimalya and I:. liurope, cult.; deciduous and monoecious: stminate flowers in racemose catkins from last season's wood: carpellary systcms few-flowered; periantl $2+2$, carpels (stigmas) 2, ovary inferior, with I basal orule centred and orthotropous. Fruit drupaceous, with remarkably lobed embryo, moulded to the shape of + diagonal tracts in the ovary-wall, storing fat. Sclerocarp of fruit with traces of loculicidal chehiscence (two shells), very hard in the wild form.

Engelhardtia spicata, a large tree often gregarious in Hill-districts, leaves compound; staminate flowers in slender catkins, 3-7 in. long; carpellary systems pendulous, 6-12 in., with densely papillose stigmatic branches. Bract and propleylls as involucre above inferior ovary. Fruit a small $\mathrm{I}$-seeded nut, with lobed cotyledons to seed. The involucre grows to a 3 -lobed leafy expansion (suggestive of Curpinus), the middle lobe $(b) 1 \frac{1}{4} \mathrm{in}$. long, as a spinning 'wing'.

Salicaceae $(2 / 200)$ including only Salix and Populus with representalive species of (haracteristic appearance and habit. Common British forms also as introductions.

Salix tetrasperma, the common type, general along river-beds, often gregarious: staminate catkins after the leaves, $2-4 \mathrm{in}$. long; flowers with 5 -Io stamens; carpellary catkins $3-5$ in. ; fruits with few $(4-6)$ seeds.

S. Uubjlanica, Weeping Willow, indig. to China, cult. in N., staminate tree commoner.

Populus ciliata, common in NW. Himalya, typical Poplar-lyabit, at I-2 miles elevation, a tall deciduous tree with viscid buds exuding balsam. leaves cordate, finely. ciliate; carpellary catkin 6-I 2 in. long, ovary with 3-4 carpels (rarely 2).

$\mathbf{P}$. euphratica, gregarious in Sind, over Tamarisk, and by rivers; leaves very variable in slape and lobing; stammate flower with 8-ro stamens; capsule commonly of 3 carpels, to $\frac{1}{2} \mathrm{in}$.

Casuarinaceae $(\mathrm{I} / 25)$ a monotypic genus of halophytic tropical trees with no functional leaves: Shoot-systems Equisetoid, with the appearance of a Conifer: Assimilatory ridged stems with whorls of scales $(6-15)$, end-ramuli shed as phyllomorphs. Flowers reduced to extreme limits: staminate flowers of I stanren, in whorled series, resembling erect catkins : carpellary flowers similarly whorled, in axil of bract, with prophylls $(a$ and $\beta$ ) as protective involucre. Gynoecium of 2 carpels (bilobed stigma), unilocular ovary with 2 superposed ovules: fertilization chalazogamic, also the oviles develop large numbers of megaspores, many with prothallial mechanism, but only one seed sets. The prophylls when sclerosed give a woody whorled conelike aggregate, and the ovary with median wing-extension to the style is a small samaroid nut (spiming). The enclosed seed has no endosperm. (Often regarded as a primitive, if not the most 'primitive' Angiosperm, and hence often at the beginning of the classification (Engler, Dicots., I 9 I 2 ).)

Casuarina equisetifolia, a tall tree, roo ft. or more, of sand-hills and strandforest throughout Malay and S. India, to tide-level, cult. and planted. Photosynthetic ramuli 6-8-ridgecl and furrowed: monoecious, cones small, $\frac{3}{4}$ in., cylindrical with about 60 fruits; seed witl stylar wing $6 \mathrm{~mm}$.

Santalaceae $(26 / 250)$, an order of essentially tropical trees with few representatives in N. Temp. (Thesium, herbaceous). Flowers, small, hermaphrodite, apetalous, 5-4-merous: perianth may be gamophyllous and tubular, the ovary inferior, with basal placenta bearing I or more ovules without integuments; Fruit r-sceded: many are hemi- or holo-parasitic.

Santalum album, Sandalwood, a small evergreen tree (40-50 ft.) of S. India, cult., gregarious in scrub-forest in My'sore, hemiparasitic on roots of adjacent plants: leaves opposite, flowers brownish-purple in small axillary and terminal panicles, 
4-lnerous; stamens 4, alternating with lobed outgrowths of receptacle-cul); ovary with central placenta filling cavity, and rudimentary orules. Fruit a small drupe, $\frac{1}{2}$ in. diam., with liard 1 -seeded sclerocarp, taken by birds.

Loranthaceae $(21 / 850)$, a group of hemiparasitic shrubs of tropical forest (Niu/sia of IV. Australia, $30 \mathrm{ft}$., non-parasitic), leaves opposite, flowers trimerous, in dichasial or triad-systems. Full type $3+3$ perianth, $3+3$ stamens, and gynoecium of 3 carjels, but so reduced that there is now no ovary-cavity or ovules; the embryosacs arise in the fused parenchynatous tissue, or the cavity is indicated by mere slits following the case of Santalum. The fruits specialize as bird-distributed 'berries', the seeds being represented by masses of endosperm with included embryos: cf. indig. Tiscum album (Nistletoe) as last northern stray, and Loranthus, 300.

Loranthus longiflorus, commonest Indian form, a large parasitic bush on Sal, Mango, and even Chir. Leaves broad and coriaceous, flowers in unilateral racemes, perianth-tube to $2 \frac{1}{2} \mathrm{in}$. long, slightly curved, scarlet or orange, bird-pollinated, with 5 free segments reflexed; filaments inserted on perianth-tube, with anthers projecting, style $55 \mathrm{~mm}$., to the level of the anthers; Berry oblong with viscid pulp, $\frac{1}{2}$ in., bird-dispersed in the manner of Mistletoe. Tiscum album common on Olive and Qucreus Jlex in NIV. lill-forest, dioecious and fly-pollinated.

Arceuthobium minutissimum, a minute parasite on Pims excelsa, shoots articulated, green, almost moss-like, $\frac{1}{4} \mathrm{in.}$; another extreme case of reduction, dioecious; staminate flower with monothecic anthers on segments of perianth $(4-5)$, the carpellary flowers only just emerging from the bark. The smallest Dicot. plant.

Proteaceac (50/1100), a remarkably isolated family (Proteales, Engler, I 9 I 2) of trees and shrubs, characteristic in S. Hemisphere (Australii, S. Africa), a few extending North (Helicia) of Malay and S. India, H. lancifolia, S. Japan, the farthest North. Filowers of very uniform organization, very distinctive, usually 4-merous, with + stamens carried upon individual zones of growth with superposed perianthsegs., and so appearing 'inserted' on them. Gynoecium of a single superior carpel (and so far an ancient apocarpous series), with many, few, or I ovule. The plants commonly present extreme xeromorphic adaptations; the flowers may be highly conspicuous and bird-pollinated, the fruits massive woody pods.

Grevillea robusta, Silky Oak of $\mathrm{E}$. Australia, cult., a large tree with compound leares, bipinnately segmented. Flowers golden-yellow in clustered racemes $\left(3-4\right.$ in.) on short spur-shoots. Fruit a coriaceous follicle, $\frac{3}{4}$ in., with $\mathrm{I}-2$ seeds. 
MONOCOTYLEDONS, a large section of Angiosperms collateral with modern Dicots., convergent only in retention of an older phase of Monochlamydeous state of floral organization, and comprising a large number of widely divergent series expressing most advanced phases of specialization in some respects, and of further reductions in others, in somatic organization as well as in floral construction. The tree-phyla (Palms) have no cambial increase of timber, and the stems are predominantly monaxial; but this is counterbalanced by the immense size of the foliage-leaves, and freely-branched inflorescence-systems. All tend to the limiting condition of a trimerous eucyclic type of flower-passing to extreme phases of reduction in anemophilous inflorescence-aggregates (Grasses), or to the extreme elaboration of individual entomophilous floral mechanisms (Orchicls). The single cotyledon of the seedling, indicated as clraracteristic of the class as a whole, is comparable with the single posterior 2-keeled prophyll of the vegetative laterals in many types, as a specialized gamoplyyllous structure replacing two initial primordia.

I. Palmae (128/1000), typically monaxial arboreal forms, with leaf-lamina secondary on a hooded petiolate scale-base, plaited fan-wise and segmented by the decay of strips of surface-tissue (palmate-type), to be subsequently elongated on a rachis-growth (pinnate-type). Wholly entire leaves occur (Corypha; King Palm, and juvenile states); bipinnation in Caryota; basal pinnules are commonly spinous, subserving xerophytic bud-protection of the apex; the leaves spirally arranged, with persistent leaf-bases (similarly protective), or abstricted with clean annular scars.

Inflorescince-systems, terminal or axillary, retain older more generalized ramification-schemes, to multibranched panicles ( $30 \mathrm{ft}$.) with thousands of flowers (to $600,000)$, or reduce to cymose systems on condensed spadix-growths: large protective bracts of leaf-base construction (spathes) may subserve protection of younger parts or developing fruits.

The growth-period is often monocarpic with T-paricle. Lianoid forms present extended internodes (Calamus) with spiny 'lora' as leaf-rachis or inflorescence-axis. The monaxial stem may reduce to a rosette-habit, with crown of fronds in the manner of a Cycad (Phoenix acaulis) or may become rhizomatous at the surface or subterranean in the nanner of advanced ferns (Nipa, swamp-type, Namnorhops, desert xerophyte).

Flowers, trinerous, and commonly much reduced, tending to dicliny with limit in dioecism, fundamentally of eucyclic type, per. $3+3$, and. $3+3$, gyn. 3 , apocarpous to typically syncarpous, with floral output reduced to I seed per loculus, and commonly restricted to I seed per flower in a berry or drupaceous fruit. The seeds store fat in endosperm-tissue, or celluloses in its walls, the endosperm simple, incomplete with carity, or 'ruminated'. The stems may' store large reserves of starch. Xeromorphic specializations of all kinds commonly prevail in all vegetative and reproductive parts. The range of type in such an isolated series is so great that classification by one character more than another is wholly empirical. Forms with older palmate leares seem more archaic on the whole, as comparatively few and residual, though advanced in other respects. The family is essentially tropical of moist regions but may range to dry tracts (Nannorhops) with external xeromorphic details. Chamacrops humilis, a bushy form, $20 \mathrm{ft}$, alone extends to Europe (with Phoeniv as introduction in Greece, \&c.). Hardy Chinese forms will flower in the open in $S$. of England.

Phoenix dactylifera, Date Palm of SW. Asia and Sahara, to I $20 \mathrm{ft}$, monaxial with pinnate foliage $(7-r 2 \mathrm{ft}$.), stcm clothed with old leaf-bases, dioecious. Inflorescence much branched, axillary; staminate fower with 6 stamens; carpellary flower of $3+3$ perianth, inner series protective, $5 \mathrm{~mm}$., and 3 carpels, apocarpous with distinct stigmas. Fruit as 3 berries, $\mathbf{x}-3$ in., each with $\mathrm{x}$ elongated secd ( $\mathrm{r}$ in.); 
the small embryo half-way along the seed, and the endosperm horny with thick cellulose walls. Cult. in rars. and propagated by suckers.

P. sylvestris of India, on low ground and along river-banks, gregarious and cult., iapped; to ft., similar in habit, leaves $7-15 \mathrm{ft}$, fruit $\mathrm{I}$ in.

$P$. acaulis common in forests of Sal, Chir, and Eng. Stem an ovoid tuber.

Chamaerops humilis, a bushy form, $20 \mathrm{ft}$, with palmate leaves, stout stem and tufted growth; the gynoccium of 3 carpels slightly cohering below, each with stigma, only one set secd. As great monocarpic type cf. :-

Corypha umbraculifera, T'alipot Paln, Ceylon and S. India, cult., to So ft., and $2 \frac{1}{2} \mathrm{ft}$. diam. annulate, growing $17-40$ years, leaves 8-i 6 ft. diam., palmate, cut in 8o-100 segments, 6 in. wicle, and halfway down. Terminal panicle 10-20 ft., pyramidal; nowers hermaphroclite, orary 3-lobed, 3-locular; Fruit of I carpel-lobe, I $\frac{1}{2}$ in. diam., drupaceous, globose; seed $18 \mathrm{~mm}$. with small embryo in horny unform endosperm with thick cellulose walls; output $\frac{1}{4}$ ton of seeds.

C. Talicra, representative sp. in Bengal, leaves cut less than lialf-way down.

Borassus flabelifer, Palmyra Palm of 'Trop. Africa, cult., to $100 \mathrm{ft}$. and $2 \mathrm{ft}$. diam., annulate; leaves on long stalks, palmate, 3-5 ft. diam., cut in 60-80 segments. Dioccious, inflorescence of massive ramuli (spadices) with close-set bract-scales and the staminate flowers in small cymose clusters, immersed under scales and emerging one at a time to function: carpellary flowers large ( $\mathrm{i}$ in.) immersed, the stigmas alone protruding, ovary with separate loculi. Fruit a massive fibrous drupe, 6 in. diam., with 3 large pyrenac in sarcocarp-pulp); seed incompletely filled with horny entosperm.

Lodoicea Seychellarum, Double Coconut, monotype of Seychelles Is., to I $20 \mathrm{ft}$, palmatc leaves, socket-base, dioecious: staminate spadis, $3 \mathrm{ft}$., flowering continuously for several years: carpellary flower $3-4$ in. dian.; Fruit a fibrous drupe, full size in 4 years, mature in $7-10$, seed $\mathrm{r} \frac{1}{2} \mathrm{ft}$. long; fruit $40 \mathrm{lb}$. weight, in clusters of $4^{-11}$ : endosperm $\frac{1}{2}$ in. deep, solid.

Cocos nucifera, Coconut, Polynesia, cult.; Stem smooth, annulate, to $80 \mathrm{ft}$, leaves pinnate, $6-12 \mathrm{ft}$, leaflets $2-3 \mathrm{ft}$., monoecious, with stout spadix ( $4-6 \mathrm{ft}$.) with drooping branches; staminate flowers numerous in upper branches, $10 \mathrm{~mm} ., 3$ outer per. seg. large and coriaceous, stamens $3+3$ : carpellary flowers few, at base of spadix-branches, I in., with massive perianth-segs. and ovary syncarpous, 3-locular. Fruit a large 3 -angled fibrous drupe ( $\mathrm{ft}$.): sclerocarp with 3 basal pores to ovaryloculi, 'cyes', one non-sclerosed. Seed 5 in. long, ovoid; endosperm white, storing fat, $\frac{1}{2}$ in. deep' (copra), cavity of seed subserving flotation, embryo imbedded opposite soft 'eye' conoidal, $\frac{1}{2}$ in. : fiuits take a year to mature; a tree produces $50-$ roo nuts a vear.

Elaeis guineensis, Oil Palm of Trop. Africa, cult. in Tropics in vars,, to $100 \mathrm{ft}$., with pinnate foliage and stem clothed with spinous leaf-bases; more or less dioccious; staminate inflorescence an aggregate of cylindrical spikes, flower with 6 stamens on a 'columu'; carpellary' system of cone-like spiral aggregates, giving clusters of fruits the size of a walnut, with oil in sarcocarp; sclerocarp with 3 ' eyes', one functional, ro mm. ; seed with white fatty endosperm.

Calamus tenuis, Cancs, of Sub-Himalya, in damp forest, stems slender, $5 \mathrm{~mm}$., forming cane-brakes, leaves pinnate, $\mathbf{I}-2 \mathrm{ft}$., with thorny flagellum of modified leaflets and inflorescence bracts; monoecious, staminate flowers small, in spikelets; carpellary flower with scales in symmetrical pattern (suggestive of phyllotaxis) on massire ovary with plumose stigmas. In fruit $\left(\frac{1}{2} \mathrm{in}\right.$.) the scales clothe the outer straw-coloured surface imbricating downwards; seed 1 , with horny endosperm.

C. Rotang of S. India, very similar; other sp. (200) may be powerful climbers, 100-400 fl., with characteristic babit, leaf-rachis 'lora', and similar flowers and fruit. Cf. large brown jolished scalyfruits of Raphia Ruffia (Sago Palm of E. Africa), $2 \frac{1}{2}$ in., borne on distichous ramuli.

Caryota urens, Mhar l'ilm, in evergreen forest of W. Ghats, and Hill forests 
of E., to $50 \mathrm{ft}$, with bipinnate frondose leaves, to $20 \mathrm{ft}$. by 10 , with cuneate segments, monocarpic: terminal inflorescence, Io-I $2 \mathrm{ft}$., flowers first, and laterals in sequence to extreme base of stem, with long and slender tassel-ramuli. Flowers in triads, carpellary ' $T$ ' and staminate $T$ '; the latter with numerous stamens $(40-45)$; carpellary flower sub-globose, ovary 3 -locular. Fruit globose, $\frac{3}{4}$ in., with I (2) seeds, endosperm hard and ruminated.

Areca Catechu, Betel-Nut Palm, cult.; to $100 \mathrm{ft}$., with smootl annulate stem, 6-9 in. diam.; leaves pinnate, $4-6 \mathrm{ft}$. Inflorescence below the leaves, monoecious, branched; staminate flowers at end of ramuli, small, normal; carpellary flowers at base of ramuli; ovary syncarpous, unilocular, with 3 stigmas, and 1 basal erect orule. Fruit a fibrous scarlet drupe, 2 in. long. Seeds 1 in., sub-globular, with beautifully ruminated endosperm, thick cellulose walls and fat-storage.

Arenga sacchifera, Malay Sago-Palm, cult.; Monocarpic: stem $24-40 \mathrm{ft}$., densely clothed with fibrous remains of leaf-bases, leares $20-28 \mathrm{ft}$., jimnate, in dense crown. Inflorescence much branched, 6-10 ft., with pendulous laterals; lateral sy-stems function basipetally, flowers commonly in triads with carpellary 'T. Staminate flowers I in. long, with numerous stamens; carpellary flower I in, diam., ovary 3-locular; Fruit 2 in.. seeds $2-3$. compressed, endosperm simple. Starch-storage in main axis (sago), spadix tapped for sugar (toddy).

Nipa fruticans, estuarine and halophytic in all Trop. Asia, giving lipa-zone on mud-banks of tidal estuaries. Stem a branched, creeping, rhizone, looting below, with crowns of pinnate fronds, $\mathrm{I} 5-30 \mathrm{ft}$. ; leaflets coriaceous, $2-4 \mathrm{ft}$. : Flowers monoecious, in packed spicate systems. Staminate flowers in cylindrical spikes, perianth segs, $3+3$. stamens 3 on a column : carpellary flowers on a globose head, 3 carpels distinct. I-seeded. In fruit the whole enlarges to a globose aggregate, I ft. diam.. of angular drupes, with surface-facets, sclerocarp fibrous-fleshy; the seeds 2-3 in., with horny endosperm and central cavity. type.

Cf. Phytelephas of Trop. Amer., Vegetable-Ivory, for very parallel ecological

II. Pandanaceae $(2 / 220)$ including comparable phases of extreme reductionspecialization, as arboreal forms with monaxial or branched habit, climbing or rhizomatous, of estuarine and tidal swamp-forest, with stilt-roots, leaves coriaceous, linear, in 3 'spires' (Screw-Pines). Commonly' regarded (since apocarpous and destitute of perianth as extremely archaic, and placed on a level with indigenous Sparganium and Typha (Engler, I 886); more probably convergent only in adaptation to swamp-habit.)

Pandanus tectorius (=odoratissimus), of coast-forest, gregarious, as a zone above high-water, and much cult.; Stems to $25 \mathrm{ft}$. on strong stilt-roots; leaves 3-5 ft. spinous on edges; dioecious; inflorescence terminal or axillary; staminate with pendulous ramuli and flowers clustered, without perianth, of numerous stamens on a 'column', in axils of white, fragrant, sheathing bracts. Carpellary flower of $4^{-1} 2$ closely aggregated carpels, each with I orule. In fruit the entire system fuses to a massive drooping 'syncarpium' of scarlet drupes, each several-seeded within a common sclerocarp. 
GRAMINEAE $(31+/ 4000)$, a great series of anemophilous Monocots. of specialized habit, essentially rlizomatous, convergent witl Palms in arboreal examples (Bambuseae), but more characteristically reduced to herbaceous habit and prairie-land formation. 'The essential departure of the grass-type centres in loss of the erect main (primary) axis, and substitution of a perennial shoot-system at the ground-level, or below, sending up erect slender shoots (culms) of seasonal habit, with greatly extended internodes and distichous leaf-arrangement, with telescopic growth-effect. Rarely monaxial (by culture) Zita, or annual (cult. cereals). The leaves are simple, with sheathing base, ligular vestige of primary apex, and secondary linear lamina-extension with parallel renation. 'The inflorescence is frecly panicled, with many grades of reduction-specialization; the flowers on ultimale ramuli reduce their perianthsegments in correlation with aggregation to special 'spikelet' inflorescence-units, of distichous construction, in which the subtending bract (lower pale) and 2-keeled posterior prophyll (upper pale) acquire a special protective value, and the limiting contact-cycle of 2 'sterile glumes' constitutes an additional involucre to the systen. In the limit the flowers of a spikelet may reduce to $\mathrm{x}$ only. The general scheme attained is remarkably uniform; herbaceous types of the N. Temp. express limiting cases of reduction-specialization in connexion with xerophytic prairie-conditions and adaptation to a short season.

As extreme examples of divergent lines in tropical regions, cf. :-

I. Bambusa, Banboo, 5o, with associated genera (I3) distinguished by special details of flower and fruit. 'The typical primary giass of tropical forest-formation, arboreal and gregarious, as nearer the prototype of the family. Woody culms to $100 \mathrm{ft}$ are shot up in a month of the wet season, with branching heads of distichous foliage and branching panicles of flowers; the latter hermaphrodite, with full spikelets, normal giumes and pales, vestigial perianth of 3 segments, 6 stamens $(3+3)$, and ovary with 3 free stigmatic plumes, unilocular with one anatropous orule on the posterior sicle (against rachis). 'The fruit is a dry caryopsis with endosperm storing starch, and is shed as 'free' grain.

II. Zea Mais, expressing an advanced type of cereal, as a special limiting case of tropical cultivation, is an artificial strain of Euchlaena mexicana. Now monaxial, monocarpic, annual, diclinous; to $\mathrm{I}_{2-\mathrm{I}} 5 \mathrm{ft}$., the vegetative branching of Euchlaena superseded: staminate flowers in a branched terminal distichous panicle, the spikelets 2-flowered and in pairs ( $\mathrm{T}$ and $\mathrm{T}^{\prime}$ ), stamens 3 , with normal glumes and pales. Carpellary flowers in lateral systems, reduced to massive axis with high whorled plyyilotaxis (4-8), spikelets paired and 2-flowered, but one merely a rudiment ; ovary with large orule and single style-filament, 106 in. long (collecting 'silks' of young (cob'). Fruit as naked grain, not detached, growth of pales and formerly protective glume suppressed; seed large, confluent with ovary-wall; endosperm solid with packed starch : cult, in many vars.

III. Saccharum officinarum, Sugar-cane, cult. in Tropics to S. Europe; $6-\mathrm{r} 2 \mathrm{ft}$. high and $2 \mathrm{in}$. diam.; herbaceous type of seasonal sarannah. Stem annulate, with short internodes ( $3-6$ in.); panicle terminal, $\mathrm{x}-2$ ft., pyramidal, plumose, multibranched; spikelets on end-ramuli paired (sessile and stalked, T and ' $\mathrm{T}$ '), I-flowered, 120 awns but the glumes densely hairy ; stamens 3 , stigmas 2, lodicules functional: seed enclosed in pales, spikelet abstricted, and dispersal by aid of tufted glumes. A nonflowering var. cult.

IV. Oryza sativa, Rice, Swamp-type, of E. Asia, the oldest food-grain, cult. in vars.: a much reduced form, $2-3 \mathrm{ft}$., with small panicle, 6 in., spikelets reduced to I flower, glumes small, pale awned (or not), stamens $3+3$, stigmas 2 , lodicules 1,resent. Spikelet detached in fruit, with seed enclosed in folded bristly pale $(8 \mathrm{~mm}$.) with awn, $8 \mathrm{~mm}$. Endosperm solid with packed starch.

As Iudian Bamboos, cf. :- 
Bambusa Tulda, common Bamboo of N. India on alluvial flats by streams, gregarious, cult., flowering casually ; culms denscly tufted, 20-70 ft., internodes $1-2 \mathrm{ft}$., and $2-4$ in, diam.; sheaths $6-9$ in. long, investing and guiding the young growth : foliage-lamina $6-10 \mathrm{in}$. by 1. Flowering-culms leafless, producing an immense multibranched panicle; spikelcts clustered, 1-3 in. long, with $4^{-6}$ fertile nowers; stamens $3+3$, anthers exserted, purple, stigmas 3 ; fruit (caryopsis) $8 \mathrm{~mm}$. long, grooved on one side, shed 'clean' from pales.

B. arundinacea, Thorny Bamboo of Cent. India, cult., gregarious in moist deciduous forest, and by streams, monocarpic: culms 50-120 ft., internodes $12-18$ in., and 6-7 diam., walls thick ( $1-2 \mathrm{in.}$ ); leaves small and thin ( $8 \mathrm{in.}$.). Large leafy branches bending over, and branchlets with sharp spines at nodes, entangled: spikelets sessile, I in., 6 stamens and 3 long plumose stigmas. Culms flower out gregariously.

B. polymorpha of damp deciduous forest, and gregarious with Teak in Burma; tufted culms $60-80$ ft., internocles $12-30$ in. and $3^{-6}$ diam. with relatively thin walls. Tops branched, gracefully bent, with branches in 'half-whorls': foliage-leaves $4^{-6}$ in., spikelets sessile, clustered, $\frac{1}{2}$ in. ; Fertile flowers 3 , with several empty glumes. MIonocarpic, flowering out gregariously at long intervals (6o years).

Dendrocalamus strictus, 'Nale Bamboo', commonest and hardiest of Indian sp., in dry deciduous forest, with Teak (Myinwa). Culms 20-50 ft. high, and $2-3$ in. diam., or $\mathrm{I}$ in. and solid in dry regions : leaves $4-10$ in., lincar : Inflorescence a distinct xeromorphic type; spikelets hairy in globose stellate heads, $\mathbf{x}$ in. diam., with hardtipped glumes, 'empty' glumes, numerous and assisting protection, fertile flowers 2-3: stamens $3+3$, no lodicules, and 1 hairy elongated stigma. Caryopsis enclosed in hard pale-sheath; flowering casually or gregariously.

D. Hamiltoni, culms to $80 \mathrm{ft}$. and $6-7$ in diam., arcuate in dense thickets, Burma, and cult., flowering sporadically ; flower capitula semi-globose, $\mathbf{I} \frac{1}{2}$ in. Conspicuous eye-like marks on lower nodes from suppressed buds.

D. giganteus, of Burma, Wabo, the largest stem; densely tufted, culms to $100 \mathrm{ft}$. and $8-\mathrm{I} 2 \mathrm{in.}$ diam., wall $\frac{1}{2} \mathrm{in}$. thick. Spikelets $\frac{1}{2} \mathrm{in.,} 2-5$ in aggregate, on long spikes, spaced about $\frac{1}{2}$ in.

Cephalostachyum pergracile, Tinwa, commonest Bamboo of Burma : tufted culms $30-40 \mathrm{ft} ., 2-3 \mathrm{in}$. diam., leaves $6-\mathrm{I}_{4}$ in. ; flowering gregariously ; Inflorescence of small globose heads, spaced at $2-3$ in. on wiry ramuli of a large leafless panicle: spikelets with many empty glumes and few fruits.

Melocanna bambusioides the most aberrant form, gregarious, Arakan : Culms distant, from vigorous rhizome extending laterally, $40-70 \mathrm{ft}$. high, $\mathrm{I}-3 \mathrm{in}$. diam., bare below; panicle $3 \mathrm{ft}$. and spikelets fascicled at the nodes, more or less diclinous, stamens $3+3$. Mlonocarpic, flowering out at intervals of 30 years or so, for hundreds of sq. miles; the characteristic fruit increases to the size of an inverted pear, $3-4$ in., with long pointed beak; the massive wall stores starch, without special protective mechanism or vitality, the single large seed, $\frac{3}{4}$ in., has no endosperm, but a massive scutellum to the small 'embryo'-region. On germination the scutellum digests directly from the ovary-wall.

GYMNOSPERMS : I. Coniferae-Pinoids, restricted to representative species of $\mathbf{N}$. Temp. genera in Himalya and Hill-forest.

Pinus excelsa, J3lue Himalyan Pine, gregarious at 6-12,000 ft., to $100-150 \mathrm{ft}$. high, cones 6-12 in., in groups of $2-5$, with soft scales and terminal umbo of $P$. Strobus type; cones ripened in second season. Five-needled.

P. longifolia, Chir, gregarious in outer Himalya at I,500-3,000 ft.; cones large and massive, 6-8 in., with hooked apophyses, ripened in second season: leaves slender and pendulous, to $18 \mathrm{in}$. Three-needled.

Also cf. P. Khasya, gregarious in Burma, cones $2-3$ in.; P. Gerardiuna of NII. 
Ilimalya, 3-nectled, cones massive, 6-9 in., seed-wing incficient ; P. Merkusii, Burma, to roo ft. and $5 \mathrm{ft}$. diam., cones $2-3 \mathrm{in}$, two-needled, associated with Eng and Penlacme, as showing possibilities of the genus.

Cedrus Deodara, gregarious in IV. Himalya, at $4-10,000 \mathrm{ft}$. in damp forests on outer ranges, to $240 \mathrm{ft}$. and $10 \mathrm{ft}$. cliam.; end-branches drooping, flexuous; foliage dark-green, needles I in., on tufted spurs; cones woody, 4-5 in.; flowering in Sept. Oct., and ripening cones in $\mathbf{1} 2-\mathbf{I} 3$ months.

Abies Pindrow, a tall tree, $200-250 \mathrm{ft}$., feathered to base, of low-level forests of W. Himalya; brauches drooping, needles $2-3$ in.; cones $4^{-7}$ in. erected, violetblack, without projecting bract-scales.

Picea Morinda, a tall tree of NIV. Himalya, 100-200 ft., with peculiar pendulous ramuli, $\mathbf{I}-3 \mathrm{ft}$., needles $\mathbf{I}-\mathbf{I} \frac{1}{2}$ in.; cones large, cylindrical, $6-8$ in., pendulous, broad brown scales with thin rounded margin.

Tsuga Brunoniana, to $120 \mathrm{ft}$. and $9 \mathrm{ft}$. diam., gregarious Central and E. Himalya; leaves $\frac{1}{2}-1$ in., pectinated, cones $\frac{3}{4}$ in.

Larix Griffithii, E. Himalya, at 2 miles elevation, deciduous, branches long and pendulous, foliage pale-green, cones $2-3$ in. long with reflexed bract-scale.

Cupressus torulosa, semigregarious in outer ranges of NIV. Himalyil, a large tree with horizontal branches; cones $\frac{1}{2}$ in., ripened in second season.

Juniperus macropodu, gregarious on dry ranges, a small tree, 50-80 ft., with dimorphic foliage ; berries blue-black, $\frac{1}{4}$ in., resinous, taken by birds.

II. Coniferae-Taxoids : the only Conifer in the $\mathrm{W}$. peninsula is Podocarpus latifolia, Hills of $\mathrm{S}$. India, a large tree with fine leaves, $4-7$ in. by $1-2$ in., pectinated in 2 rows, and appearing opposite, with effect of pinnate foliage: seed $\frac{3}{4} \mathrm{in}$. globular, purple, succulent, erected on elongated succulent axis ( $\mathrm{r}$ in.).

Taxus baccata, in shady ravines of Himalya, at 2 miles elevation, and Hills of Burma, show's range of this ancient type.

III. Cycadaceae, with monaxial palm-habit, and crown of pinnate foliage-leaves. Cy:as-type alone represented, $5 \mathrm{sp}$.

Cycas circinalis moist forests of S. India, I $5-40 \mathrm{ft}$, and 100 yrs. ; sten with leaf-scars, foliage-leaves $5^{-9} \mathrm{ft}$. , pinnules flat. Staminate cone $\mathbf{I}-\mathbf{2} \mathrm{ft}$. ; Carpels on the main axis, to $\mathrm{I} \mathrm{ft}$. long, with $6-\mathrm{I} 2$ ovules. Seeds 1 in., yellow-red sarcotesta; endosperm storing starch.

C. revoluta of Japan, commonly cult., stem $6 \mathrm{ft}$. with old leaf-bases, leaves pinnate, 2-6 ft., margins revolute; carpels $4^{-9}$ in. long, with $4-6$ ovules: cf. $C$. siamensis in Eng forest, carpels with 2 basal ovules. C. Rumphii of beach-forest, Coco islands, may give $50 \mathrm{ft}$. shaft and $18 \mathrm{in}$. diam., seeds $2-3 \mathrm{in}$. long. Interest botanical rather than silvicultural.

While the Cycads with the specialized monaxial habit of Tree-Ferns and Palms can never have been the precursors of modern Angiospermous trees, special interest attaches to Gnetales; less to Ephedra with reduced foliage and photosynthetic ramuli than to Gnetum, species of which still remain in the form of lianoid types in the original station of Tropical forest: $c f .-$

Gnotum scandens, an immense evergreen climber of Hill-forest of S. India and Burma, trunk $9^{-12}$ in. broad, flattened, with anomalous vascular structure; leaves decussate, broad, net-reined; flowers, dioecious, whorled, in clustered catkin-like systems, 2 in. : Sced, r in., drupe-like with edible orange-coloured 'sarcotesta'. 


\section{DATE DUE}
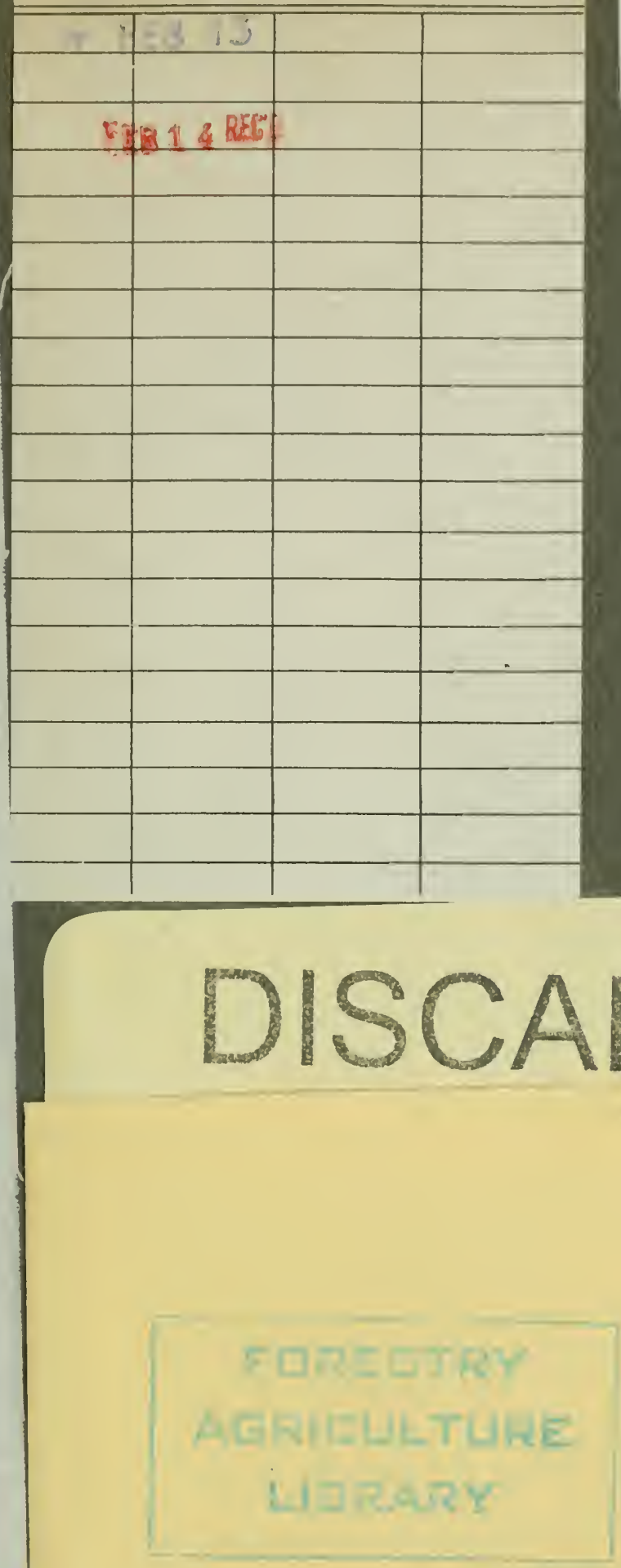
UNIVERSTY OF B.C. LIBRARY

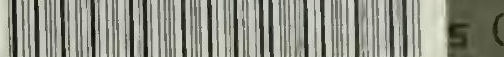
39424006231382 
